\title{
Synthesis and Characterization of Novel Calcium-Silicate Nanobioceramics with Magnesium: Effect of Heat Treatment on Biological, Physical and Chemical Properties
}

\author{
Konstantina Kazeli ${ }^{1,2, *}$, Ioannis Tsamesidis ${ }^{2,3} \mathbb{D}^{\mathbb{D}}$, Anna Theocharidou ${ }^{3}$, Lamprini Malletzidou ${ }^{4} \mathbb{D}$, \\ Jonathan Rhoades ${ }^{5}$, Georgia K. Pouroutzidou ${ }^{4}{ }^{6}$, Eleni Likotrafiti ${ }^{5}$, Konstantinos Chrissafis ${ }^{4}$, \\ Theodoros Lialiaris ${ }^{1}$, Lambrini Papadopoulou ${ }^{6}\left[\right.$, Eleana Kontonasaki ${ }^{3} \mathbb{D}$ and Evgenia Lymperaki ${ }^{2, *}$
}

check for

updates

Citation: Kazeli, K.; Tsamesidis, I.; Theocharidou, A.; Malletzidou, L.; Rhoades, J.; Pouroutzidou, G.K.; Likotrafiti, E.; Chrissafis, K.; Lialiaris, T.; Papadopoulou, L.; et al. Synthesis and Characterization of Novel Calcium-Silicate Nanobioceramics with Magnesium: Effect of Heat Treatment on Biological, Physical and Chemical Properties. Ceramics 2021, 4 628-651. https://doi.org/10.3390/ ceramics 4040045

Academic Editors: Gilbert Fantozzi, Margarita A. Goldberg and Elisa Torresani

Received: 25 October 2021 Accepted: 22 November 2021 Published: 27 November 2021

Publisher's Note: MDPI stays neutral with regard to jurisdictional claims in published maps and institutional affiliations.

Copyright: (C) 2021 by the authors Licensee MDPI, Basel, Switzerland. This article is an open access article distributed under the terms and conditions of the Creative Commons Attribution (CC BY) license (https:// creativecommons.org/licenses/by/ $4.0 /)$.
1 School of Health Sciences, Faculty of Medicine Alexandoupoli, Democritus University of Thrace, GR-68100 Alexandroupolis, Greece; lialiari@med.duth.gr

2 Department of Biomedical Sciences, International Hellenic University, GR-57400 Thessaloniki, Greece; itsamesidis@auth.gr

3 Department of Prosthodontics, School of Dentistry, Faculty of Health Sciences, Aristotle University of Thessaloniki, GR-54124 Thessaloniki, Greece; antheo@dent.auth.gr (A.T.); kont@dent.auth.gr (E.K.)

4 Advanced Materials and Devices Laboratory, School of Physics, Faculty of Sciences, Aristotle University of Thessaloniki, GR-54124 Thessaloniki, Greece; labrinim@auth.gr (L.M.); gpourout@physics.auth.gr (G.K.P.); hrisafis@physics.auth.gr (K.C.)

5 Department of Food Science and Technology, International Hellenic University, GR-57400 Thessaloniki, Greece; rhoadesjonathan@gmail.com (J.R.); likotraf@food.teithe.gr (E.L.)

6 School of Geology, Aristotle University of Thessaloniki, GR-54124 Thessaloniki, Greece; lambrini@geo.auth.gr

* Correspondence: kkazeli@physics.auth.gr (K.K.); evlimper@ihu.gr (E.L.)

Abstract: Glass-ceramic nanopowder with a composition of $55 \mathrm{SiO}_{2}-35 \mathrm{CaO}-10 \mathrm{MgO}(\mathrm{mol} \%)$ was synthesized by the sol-gel method and was heat treated at three temperatures $\left(\mathrm{T} 1=835^{\circ} \mathrm{C}, \mathrm{T} 2=1000{ }^{\circ} \mathrm{C}\right.$, $\left.\mathrm{T} 3=1100^{\circ} \mathrm{C}\right)$ in order to obtain different materials $(\mathrm{C} 1, \mathrm{C} 2, \mathrm{C} 3$, respectively) varying in crystal structure. Bioactivity and oxidative stress were evaluated in simulated body fluid (SBF) for various time periods (up to 10 days). The structure of the synthesized materials and their apatite-forming ability were investigated by X-ray diffractometry (XRD), Fourier transform infrared spectroscopy (FTIR), Scanning Electron Microscopy and Energy Dispersive Spectroscopy (SEM/EDS). The antibacterial properties of the synthesized materials were evaluated against three Gram-positive and four Gramnegative bacterial strains and their biocompatibility was verified on a primary cell line of human gingival fibroblasts (HGFs) by the MTT (3-[4, 5-dimethylthiazol-2-yl]-2, 5 diphenyl tetrazolium bromide) assay. The crystallization of the materials was increased by sintering temperature. Heat treatment did not inhibit the bioactive behavior of the materials as apatite formation started after 3 days in SBF. C2, C3 showed some indications of apatite forming even from the first day. Regarding cell viability, a variety of biological behaviors, concerning both dose and time points, was observed between the positive control and the tested materials by both the MTT assay and oxidative stress analysis. In conclusion, the nanobioceramic materials of this study possess a multitude of attractive physicochemical and biological properties that make them suitable candidates for bone regeneration applications, fillers in nanocomposite scaffolds, or as grafts in bone cavities and periodontal lesions.

Keywords: silica-based nanoparticles; bioactivity assay; oxidative stress; antibacterial properties; biocompatibility assay; human gingival fibroblast (HGFs)

\section{Introduction}

Bioactive ceramics and glass-ceramics are a unique group of synthetic materials that react with biological fluids, presenting enhanced capability of biointegration [1-6]. Numerous studies, both in vitro and in vivo, have demonstrated the ability of these materials to bond with living tissues, especially bone, through the development of a surface 
apatite layer [7-13]. Their physical, chemical, biological, and mechanical properties are of paramount importance and determine their suitability for various biomedical applications [14-19], for example, in bone regeneration and dentine bonding of root filling materials.

Bioceramic nanoparticles have attracted the interest of the scientific community because of their advantages and attractive properties, including high surface area, green catalytic capability, green adsorbents capability, targeted drug delivery potential, and nonhemolytic or even antibacterial properties [20-26]. There is a growing body of literature aiming to evaluate the toxicity of nanomaterials and correlate it with specific nanoparticle properties. The biocompatibility and cytotoxicity of biomaterials are key issues that must be addressed at a pre-clinical stage, before biomedical applications [27-30]. Research has shown that the smaller the size of the bioactive glass particles (nanoparticles), the higher their bioactivity and the more suitable they are for biomedical applications. However, different types of silica-based nanomaterials, such as fumed silica, non-porous silica, and porous silica materials, have different cytotoxicity responses, with the last ones exhibiting the lowest values in a broad range of cell types [31-38].

The results of recent in vivo studies with bioactive glass nanoparticles indicated that these materials do not produce toxic shock or systemic toxicity and inflammation, and exhibit antimicrobial properties [21,39-42]. One of the most common tests for the evaluation of biological responses, according to ISO 10993, is the in vitro test of cellular toxicity. Many research groups characterize cell cytotoxicity as the initial step in determining whether or not a material's biocompatibility is achieved [33,43,44].

Bioactive glass-ceramics can be synthesized with either melt-derived or sol-gel methods. The sol-gel method is commonly used for the synthesis of ceramic nanoparticles. It is an inorganic polymerization reaction based on a dual hydrolysis/polycondensation mechanism that can be accordingly modulated for the desired result. The process involves the use of alkoxide precursors diluted in a solvent (i.e., alcohol) in the presence of water. By monitoring the basic parameters affecting the formation of nanoparticles, such as the $\mathrm{H}_{2} \mathrm{O}$ /alkoxide ratio, sintering temperature and time, aging temperature, and drying conditions, it is possible to produce either a sol having a colloidal nanoparticle dispersion or a gel where the macromolecule that spreads throughout its volume is formed [17,45-47]. This method results in materials with high surface area, which is correlated with an increase in the growth rate of apatite layer and better bioactivity.

There are two dominant categories in ceramic biomaterials, calcium-phosphate ceramics, and calcium-silicate ceramics, which have comparable biological properties. Calciumsilicate ceramics have shown higher bioactivity than calcium phosphates and fast apatiteforming ability $[48,49]$. They have also been associated with enhanced proliferation and differentiation of various cell types [50,51]. Although calcium silicates have similar properties to calcium-phosphate ceramics, they are more soluble, which causes cell death through significant increase in $\mathrm{pH}$ and alkaline-induced toxicity [52,53].

Magnesium — an important trace element of bone and extracellular matrix (ECM) - is closely linked to cellular differentiation and calcification of hard tissues and it also has an indirect effect on metabolism. The addition of magnesium to calcium-silicate systems affects their mechanical properties, reduces $\mathrm{pH}$, accelerates bone formation, directly stimulates osteoblast proliferation, and enhances cellular differentiation [54-57]. Consequently, calcium-silicate nanomaterials containing Mg possess superior mechanical properties, enhance bone formation, and lead to higher expression of osteogenic differentiation gene markers [58-65].

The objective of the present study was to synthesize bioceramic nanomaterials in the ternary $\mathrm{SiO}_{2}-\mathrm{CaO}-\mathrm{MgO}$ system through the sol-gel method and to evaluate their in vitro bioactivity, biocompatibility, and antibacterial properties after thermal treatment at various temperatures. 


\section{Materials and Methods}

\subsection{Glass-Ceramic Synthesis of Bioceramic Nanopowder}

In the present study, the Stöber-based sol-gel method that was developed for the synthesis of silica nanoparticles was used to synthesize a bioceramic nanopowder of the composition $55 \mathrm{SiO}_{2}-35 \mathrm{CaO}-10 \mathrm{MgO}$ (in mol \%) by an acid-based catalyzed hydrolysis of TEOS [66-70]. In brief, silicon oxide in the form of tetraethyl orthosilicate (TEOS) solution was added in a mixture of d.d. $\mathrm{H}_{2} \mathrm{O}$, ethanol and $2 \mathrm{M}$ nitric acid $\left(\mathrm{HNO}_{3}\right)$. Then, while maintaining continuous magnetic stirring at $400 \mathrm{rpm}$ and after the completion of the hydrolysis of TEOS, the remaining reagent-soluble calcium and magnesium nitrates $\left(\mathrm{Ca}\left(\mathrm{NO}_{3}\right)_{2} \cdot 4 \mathrm{H}_{2} \mathrm{O}, \mathrm{Mg}\left(\mathrm{NO}_{3}\right)_{2} \cdot 6 \mathrm{H}_{2} \mathrm{O}\right)$ were added in the mixture. Mechanical stirring was applied for $1 \mathrm{~h}$ at room temperature, and then the beaker containing the mixture was placed in a conventional ultrasonic bath, whereupon the $2 \mathrm{M}$ ammonia solution was added dropwise, at a rate of $1 \mathrm{~mL} / \mathrm{min}$. Gelation was achieved at around $14 \mathrm{~h}$ after the addition of ammonia by the conversion of the solvent to a soft gel. The mixture was dried at $75^{\circ} \mathrm{C}$ for 2 days to complete the aging stage and receive a dry gel. In order to decompose the formed agglomerates, the synthesized material was subjected to wet mechanical ball milling after the sintering process [71-77]. The milled material was then dried in a low temperature oven at $30-40{ }^{\circ} \mathrm{C}$ and stored in a desiccator.

\subsection{Morphological and Structural Characterization of Synthesized Bioceramic Nanopowder}

\subsubsection{Differential Thermal and Thermogravimetric Analysis (TG-DTA)}

The thermal behavior and properties of the synthesized powder were analyzed using differential thermal analysis and thermogravimetric analysis (TG-DTA). A quantity of $36.5 \mathrm{mg}$ of the initial nanopowder was heated from $26{ }^{\circ} \mathrm{C}$ to $1380{ }^{\circ} \mathrm{C}$ with a heating rate of $10^{\circ} \mathrm{C} / \mathrm{min}$, using a Setaram SETSYS $16 / 18\left(1750^{\circ} \mathrm{C}\right.$ rod $)$ device. All measurements were performed in alumina crucibles and under air flow $(50 \mathrm{~mL} / \mathrm{min})$.

Based on the results of the thermal analysis performed after the aging stage, and, in particular, on the characteristic crystallization temperature $\left(T_{c}\right)$, glass transition temperature $\left(\mathrm{T}_{\mathrm{g}}\right)$, and peak temperature $\left(\mathrm{T}_{\mathrm{c}}, \mathrm{p}_{\mathrm{k}}\right)$, the initial powder was divided into three isomeric quantities, and each one was heated to a different temperature in the region of $800-1100{ }^{\circ} \mathrm{C}$ [78]. The three temperatures selected for further study were: $835^{\circ} \mathrm{C}(\mathrm{C} 1)$, which corresponds to the beginning of the crystallization process, $1000^{\circ} \mathrm{C}(\mathrm{C} 2)$, which corresponds to the end of the crystallization process, and $1100{ }^{\circ} \mathrm{C}(\mathrm{C} 3)$, which corresponds to the temperature where the ternary system exhibits no further crystallization. All the samples were heated from room temperature with a heating rate of $10^{\circ} \mathrm{C} / \mathrm{min}$ under air and then allowed to cool to room temperature.

\subsubsection{Structural Characterization}

The synthesized materials were in the nanoscale level as evidenced by Dynamic Light Scattering (DLS) measurements [66]. Structural characterization of the synthesized bioceramic nanopowder was carried out by X-ray diffractometry (XRD) and Fourier transform infrared spectroscopy (FTIR), while their morphology was evaluated with Scanning Electron Microscopy and Energy Dispersive Spectroscopy (SEM-EDS). All the FTIR spectra were obtained with the $\mathrm{KBr}$ pellet technique using a Perkin-Elmer FTIR spectrometer, model Spectrum 1000, in the MIR spectral region $\left(4000-400 \mathrm{~cm}^{-1}\right)$, with a resolution of $4 \mathrm{~cm}^{-1}$ and 32 scans. The XRD measurements were performed using a two-cycle Rigaku Ultima $^{+}$X-ray diffractometer (operating at $40 \mathrm{kV} / 30 \mathrm{~mA}$, with $\mathrm{CuK}_{\alpha}$ radiation, in BraggBrentano geometry) and the operating conditions were: step $0.02^{\circ}$, count $2.5 \mathrm{~s} / \mathrm{step}$, in the angle range of $5-75^{\circ}$. The XRD patterns were identified with JCPDS-ICDD. Open-source FullProf Suite program (version January 2021) was used for the Rietveld analysis [79]. The morphological characterization and evaluation, and the stoichiometric composition of the samples were evaluated with SEM-EDS using a JEOL electron microscope, model JMS-6390LV, equipped with an Oxford INCA Energy Dispersive Spectroscope. For the 
microanalysis, the samples were coated with a carbon layer of about $200 \AA$ Á to achieve conductivity of the materials under study.

\subsection{In Vitro Apatite-Forming Ability in Simulated Body Fluid}

The in vitro apatite-forming ability of the heat-treated bioceramic powders was evaluated by immersion in a conventional simulated body fluid (c-SBF) under renewal conditions $[69,80]$. The bioceramic powder mass to the liquid volume ratio of the solution was constantly kept at $1.5 \mathrm{mg} / \mathrm{mL}$ [80]. The replacement of the SBF solution was performed $6 \mathrm{~h}$ after the first immersion, then at $24 \mathrm{~h}$ ( 1 day) and then every other 2 days $(0,1,3,5,7$, and 10 days). All samples remained at a constant temperature of $37^{\circ} \mathrm{C}$ in an incubator. After each time point, the samples were centrifuged and dried in a low temperature incubator at $30-40{ }^{\circ} \mathrm{C}$. All experiments were performed in triplicate.

\subsection{Preparation of Cell Lines of Human Fibroblasts (Human Gingival Fibroblasts, HGFs)}

Primary cultures of HGFs were established from gingiva biopsy of a healthy donor during the extraction of premolars or third molars, after approval by the Ethical Committee of the Institutional Review Board (\#11/23 November 2017 Absence of inflammation and root caries were the necessary conditions in order to perform the biopsy. More specifically, small pieces (1-2 $\mathrm{mm}$ ) of gingival tissue were placed in $25 \mathrm{~cm}^{2}$ culture flasks with Dulbecco's modified essential medium (DMEM, Biochrom, Cambridge, UK) supplemented with $10 \%$ fetal bovine serum (FBS, GibcoBRL) and antibiotics/antimycotics (penicillin, streptomycin, amphotericin B (GibcoBRL, Grand Island, NY, USA). Cell culture was performed in a sterilized incubator at $37 \pm 1{ }^{\circ} \mathrm{C}$ and $5 \% \mathrm{CO}_{2}, 95 \%$ atmospheric pressure, and $100 \%$ humidity. When the flask became $80-90 \%$ confluent, cells were transported by trypsinization (solution trypsin $0.25 \% 1 \mathrm{mM}$ EDTA solution (GIBCO/Invitrogen)) to a larger flask of $75 \mathrm{~cm}^{2}$. HGFs from 3 rd to 6 th passages were used.

\section{Mitochondrial Activity-MTT Assay}

In order to measure the cell viability, the indirect biocompatibility test of MTT (3(4,5-dimethylthiazol-2-yl)-2,5-diphenyltetrazolium bromide) was performed. Eluates were collected after $24 \mathrm{~h}$ incubation time with the nanoparticles at a concentration of $1 \mathrm{mg} / \mathrm{mL}$ in Dulbecco's minimal essential medium, DMEM. After centrifuging, the supernatant was collected and passed through $0.22 \mu \mathrm{m}$ filters. More specifically, cells of HGFs $\left(3 \times 10^{4}\right.$ cells per well) were seeded in 96-well plates to allow cell attachment. After $24 \mathrm{~h}$ of cell culture, DMEM was removed and replaced with eluates of the three tested materials at two concentrations (125 and $250 \mu \mathrm{g} / \mathrm{mL}$ ). HGFs cultured in DMEM supplemented with FBS and antibiotics served as positive control, while HGFs cultured in DMEM without FBS served as negative control. Analysis of mitochondrial activity and thus cell proliferation was succeeded by measuring the mitochondrial dehydrogenase activity of living cells verified by the capability of transforming the yellow tetrazolium salt into blue formazan crystals. After 1,3 and 5 days, the culture medium was removed from each well, followed by washes with PBS, and then DMEM was placed in each well. Following that, MTT solution was added in each well ( $10 \%$ of the total volume per well) and $3 \mathrm{~h}$ incubation at $37{ }^{\circ} \mathrm{C}$ and $5 \% \mathrm{CO}_{2}$ followed. After this period, the medium containing the MTT solution was discarded, and the insoluble formazan was dissolved with dimethyl sulfoxide (DMSO). Cell viability was evaluated by measurement of optical density with an ELISA-spectrophotometer (Epock, Biotek) at double wavelength (at 540-630 nm). The experiments were performed in triplicate. Statistical analyses were performed using Microsoft Excel 2007. Independent sample $t$ test was used to compare between means. In all statistical analysis, level of significance ( $p$-value) was set at $\alpha=0.05$. The level of statistical significance was $0.05(p<0.5)$. 


\subsection{Antibacterial Assay}

Seven bacteria were used in the experiments: Bacillus cereus, Staphylococcus aureus ATCC 6538, Listeria monocytogenes Scott A, Escherichia coli O157:H7 (non-toxigenic) NCTC 12079, Salmonella enterica serovar Typhimurium, S. enterica serovar Enteritidis PT4, and Pseudomonas aeruginosa. Cultures were resuscitated from frozen stocks by streaking onto plate count agar (PCA) plates. To prepare cultures for the experiments, $10 \mathrm{~mL}$ of nutrient broth (NB) was inoculated with bacterial culture from a PCA plate and incubated for $24 \pm 2 \mathrm{~h}$ at $37^{\circ} \mathrm{C}$. A $100 \mu \mathrm{L}$ aliquot of this culture was then used to inoculate fresh NB $(10 \mathrm{~mL})$, which was then incubated for $24 \pm 1 \mathrm{~h}$ at $37^{\circ} \mathrm{C}$. A $1 \mathrm{~mL}$ aliquot of this broth culture was centrifuged at $13,000 \times g$ for $5 \mathrm{~min}$ and the supernatant discarded. The cell pellet was resuspended in $1 \mathrm{~mL}$ Ringers diluent solution and the resulting suspension diluted 1 in 10 with Ringers solution. The viable bacteria in the inocula were enumerated by colony counting on PCA $\left(37^{\circ} \mathrm{C}, 24 \mathrm{~h}\right)$.

\subsubsection{Growth Experiments}

Growth experiments were carried out using a Bioscreen $C$ instrument, which measures optical density changes in liquid media in microtiter plate wells. Each well contained $120 \mu \mathrm{L}$ $\mathrm{NB}$ of $2.5 \times$ normal concentration (NB2.5), $150 \mu \mathrm{L} 1 \mathrm{~g} / \mathrm{L}$ test compound (control: sterile distilled water), and $30 \mu \mathrm{L}$ bacterial suspension (sterility control: sterile distilled water). The final concentration of the antimicrobial compounds in the test wells was therefore $0.5 \mathrm{~g} / \mathrm{L}$. Plates were loaded into the Bioscreen C, which was set at $37^{\circ} \mathrm{C}$ with optical density measurements at $600 \mathrm{~nm}$ every $30 \mathrm{~min}$ for $24 \mathrm{~h}$.

\subsubsection{Statistical Data Analysis of the Bacterial Cultures}

All experiments were performed in triplicate and repeated once, giving six replicates in total. At the end of the experiment, the collected data were exported to Microsoft Excel for processing. For each triplicate measurement, the data were adjusted for initial absorbance by subtracting the mean of the time zero values from all measurements. Semi-log graphs were plotted of optical density (OD) against time, the period of maximum exponential growth was selected and the growth rate over the selected period was calculated using the formula

$$
\text { Growth Rate }=\frac{\ln \left(O D t_{2} / O D t_{1}\right)}{t_{2}-t_{1}}
$$

where $t_{1}$ is the first time point of the selected exponential growth period and $t_{2}$ is the last. The growth rates of the controls and the test wells in each individual Bioscreen run were normalized by dividing each individual value by the mean of the three control values. Data from the different runs were then combined, and the normalized growth rates in the test wells were compared with those in the control wells. Lag phases were approximated by determining the time before an increase in absorbance (of at least 0.01 absorbance units) was observed at the start of growth.

\subsection{Fluorescence Analysis for the Detection of ROS Levels}

For the detection of intracellular reactive oxygen species (ROS) levels generated during cell culture with the eluates of nanobioceramics, we employed the cell-permeable ROSsensitive probe Dihydroethidium (DHE). Measurement of fluorescence was performed on the supernatant received from cell culture wells before the addition of DMSO at each time point $(1,3$, and 5 days) at two concentrations (125 and $250 \mu \mathrm{g} / \mathrm{mL})$ for the three tested materials. The received supernatant from cell culture wells without tested materials was used as control. For fluorescent measurements, an excitation wavelength of $480 \mathrm{~nm}$ and emission wavelength of $576 \mathrm{~nm}$ were used. Oxidation of DHE $5 \mu \mathrm{M}$ (incubated for $1 \mathrm{~h}$ ) in supernatants was monitored by measurement of the fluorescence in 96-well blackwalled microplates (Corning ${ }^{\circledR}$, Sigma Aldrich, Merck KGaA, Darmstadt, Germany) using a TECAN Trading ASC Fluorescence Multimode Microplate Reader. The relative fluorescence is expressed as "\% maximal emission" as determined with the software "Magellan". 


\section{Results}

3.1. Morphological and Structural Characterization of Synthesized Bioceramic Nanopowders

3.1.1. Thermogravimetric Results

The thermal behavior of the synthesized material is depicted in Figure 1.

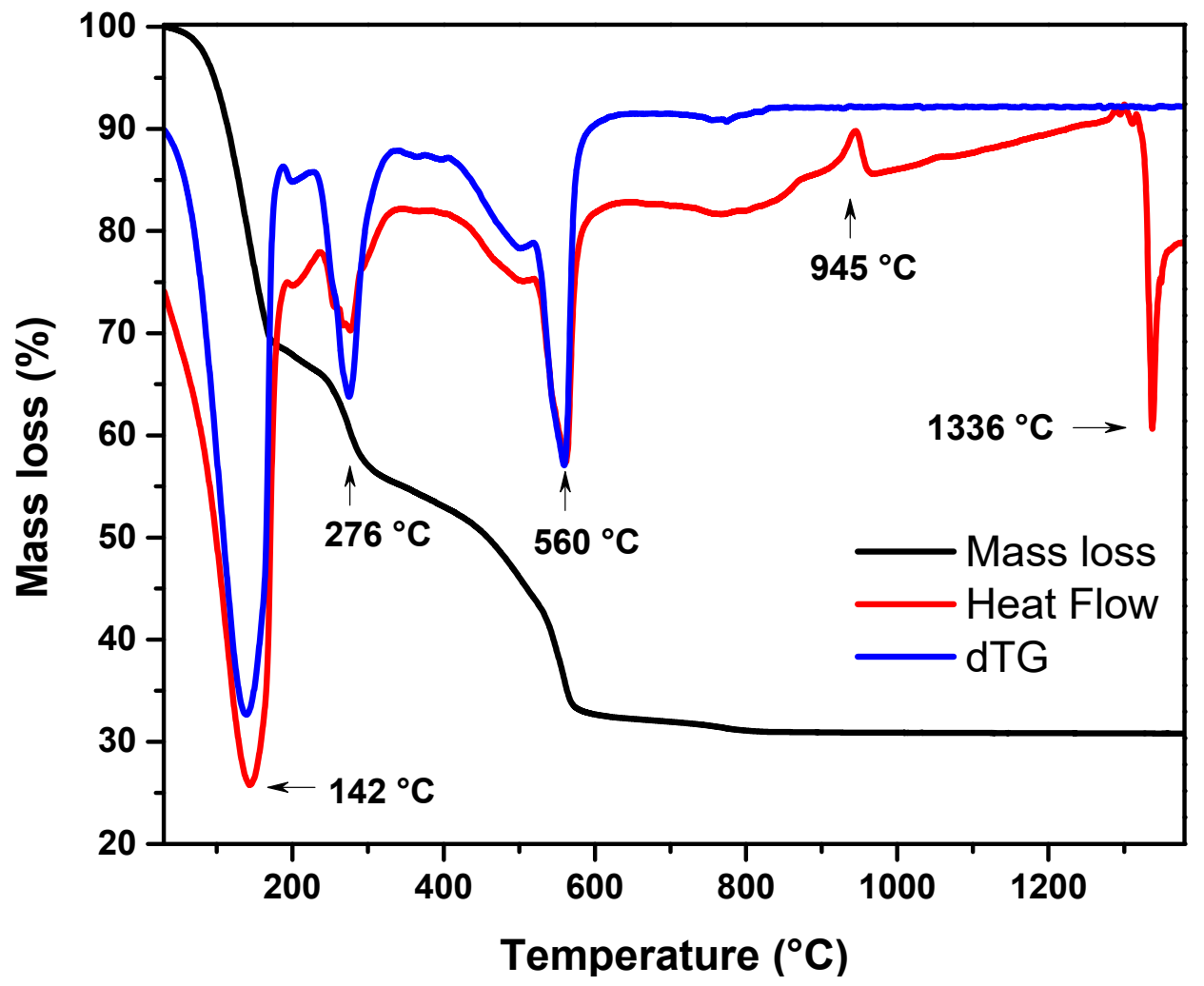

Figure 1. TG-DTA thermograph of the initial synthesized material.

The TG-DTA analysis performed on the material under study (Figure 1) showed a total mass loss of $70 \%$ up to $835^{\circ} \mathrm{C}$, which occurred in four steps:

(a) 25-190 ${ }^{\circ} \mathrm{C}$ : Mass loss of about $31.6 \%$, which was associated with an endothermic peak at $142{ }^{\circ} \mathrm{C}$. It was attributed to the loss of adsorbed water and the degradation of $\mathrm{HNO}_{3}$. As reported in the literature, there are two forms of water "trapped" in the crystalline cell structure of the sol-gel-based nanopowder when it is in the gel state: the unbound water inside the gel structure and water [81-83].

(b) $\quad 190-333^{\circ} \mathrm{C}$ : Mass loss of about $13 \%$, which was associated with an endothermic peak at $276{ }^{\circ} \mathrm{C}$. It was attributed to incineration of organic residues of ethanol and acetone [84]. In addition, in this temperature range, the decomposition of the chemically adsorbed water was attributed to the decomposition of the polycondensation reaction.

(c) $\quad 333-640{ }^{\circ} \mathrm{C}$ : Mass loss of about $23.1 \%$, associated with an endothermic peak at $560{ }^{\circ} \mathrm{C}$. According to the literature, it is attributed to the decomposition of calcium nitrate tetrahydrate, which is first converted to anhydrous calcium nitrate $\mathrm{Ca}\left(\mathrm{NO}_{3}\right)_{2}$ (eliminating $\mathrm{H}_{2} \mathrm{O}$ at about $350{ }^{\circ} \mathrm{C}$ ) and then it decomposes into $\mathrm{CaO}$ and $\mathrm{NO}_{2}[85,86]$.

(d) $\quad 640-835{ }^{\circ} \mathrm{C} / 1000{ }^{\circ} \mathrm{C}$ : Mass loss of $1.4 \%$ due to dehydroxylation $[81,83]$, achieved above $850{ }^{\circ} \mathrm{C}$. When the viscous flow began and the hydroxyl groups reacted, the particles came closer together on the surfaces of the gels, thereby eliminating the inner pores and gaps. This was consistent with the Heat Flow curve, since there was no indication of a decomposition process, while at the same time there was no significant loss of mass at that particular temperature range and above.

The results of the above study showed a large mass loss $(69 \%)$ up to $835{ }^{\circ} \mathrm{C}$. This was due to the fact that the thermal behavior of the material was measured after the aging 
stage of $75^{\circ} \mathrm{C}$ but before the drying stage (usually up to $750-800{ }^{\circ} \mathrm{C}$ ). For this reason, the material had "retained" large quantities of bound and unbound $\mathrm{H}_{2} \mathrm{O}$, water vapor, gases, nitrates, and other byproducts created during its preparation process, resulting in a greater evaporation rate at $75{ }^{\circ} \mathrm{C}$.

The Heat Flow curve showed a double exothermic peak, which started at $835^{\circ} \mathrm{C}$ and ended at about $970{ }^{\circ} \mathrm{C}$, with the most intense one located at $945^{\circ} \mathrm{C}$. This double peak was attributed to multiple crystallization mechanisms, such as these of enstatite, bredigite, and wollastonite $[87,88]$. This was supported by the FTIR and XRD analysis of samples C2 and C3, as discussed in the respective paragraph below. In addition, a low intensity exothermic peak observed at $1053^{\circ} \mathrm{C}$ was probably attributed to poor crystallization. Finally, at $1336^{\circ} \mathrm{C}$ an intense endothermic peak was observed with zero mass loss, which was attributed to melting of the material. It is important to mention that no further mass loss was observed from $835{ }^{\circ} \mathrm{C}$ (initiation of crystallization) until the end of the thermal measurements, suggesting a material with stable structure, without significant mass fluctuations.

\subsubsection{FTIR Analysis of Heat-Treated Bioceramic Materials}

The obtained FTIR spectra before immersion in SBF are presented in Figure 2.

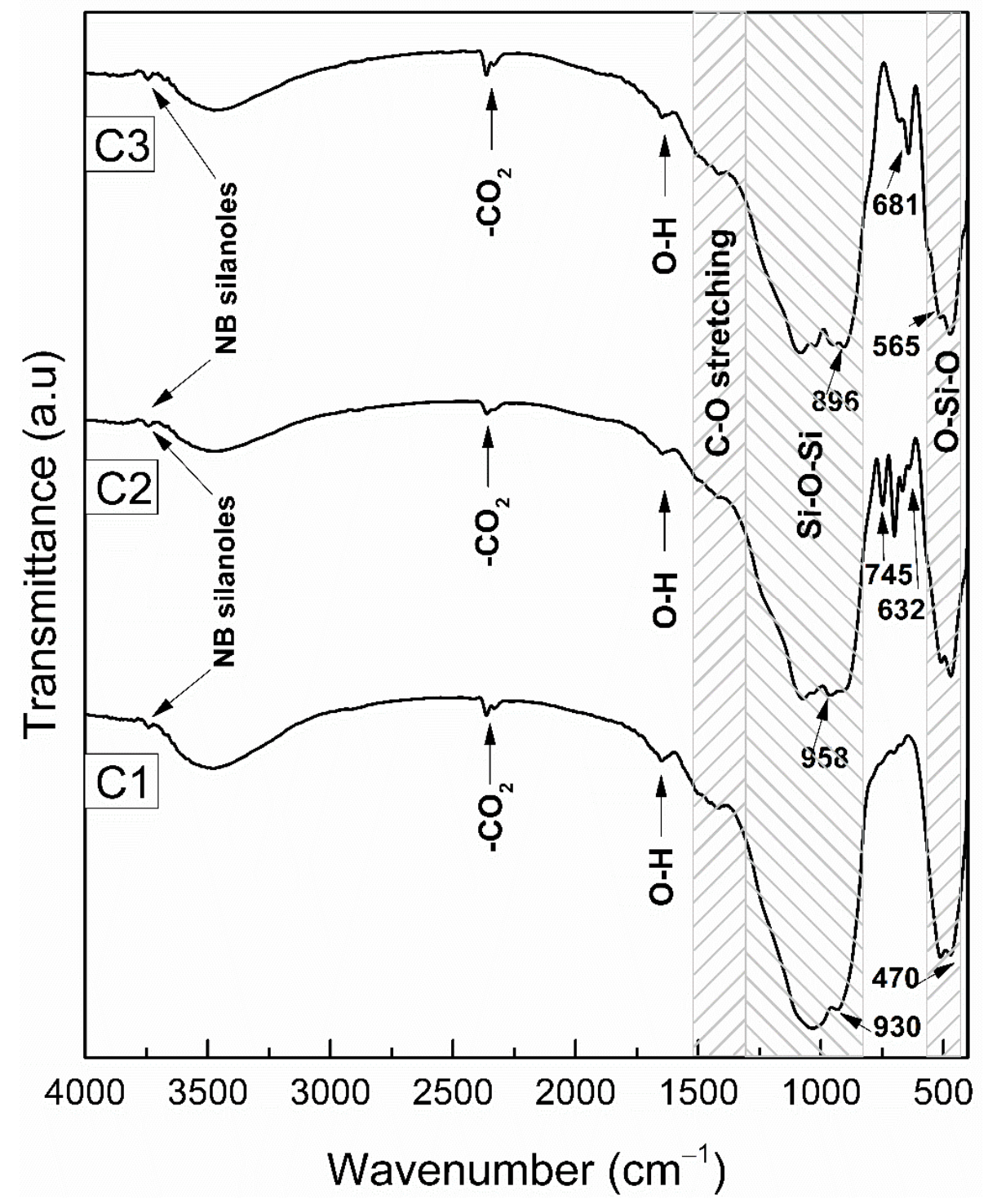

Figure 2. FTIR spectra before the immersion of the three samples in SFB. 
All three materials, regardless of their heat treatment temperature, exhibited the characteristic broad bands of silicate glass [89]. Specifically, the FTIR spectra of the studied materials revealed two strong and broad bands at $1200-900 \mathrm{~cm}^{-1}$ with a shoulder at about $1220 \mathrm{~cm}^{-1}$ — which were attributed to the asymmetric stretching vibrations of $\mathrm{Si}-\mathrm{O}-\mathrm{Si}$ [90] and at $580-400 \mathrm{~cm}^{-1}$-which were attributed to the rocking vibration of the $\mathrm{O}-\mathrm{Si}-\mathrm{O}$ bond [91-94]. Additional common features in the FTIR spectra of the three materials were: (a) a weak band at $1640 \mathrm{~cm}^{-1}$ and a wide one at $3600-3200 \mathrm{~cm}^{-1}$, which were mainly associated with the bending and stretching vibrations of the $\mathrm{O}-\mathrm{H}$ bond, respectively, owing to the presence of moisture in the sample; (b) a weak band at $3780 \mathrm{~cm}^{-1}$, which was attributed to a hydroxyl group of non-bridged silanoles (single silanols); and (c) a very weak and wide band in the spectral area of $1500-1400 \mathrm{~cm}^{-1}$, which was attributed to the asymmetric $\mathrm{C}-\mathrm{O}$ stretching vibration of the $\mathrm{CO}_{3}{ }^{-2}$ group.

The FTIR spectrum of $\mathrm{C} 1$ was attributed mainly to a silicate glass while the spectra of $\mathrm{C} 2$ and $\mathrm{C} 3$ revealed new sharp bands that were indicative, as expected, of the creation of crystalline phases. More specifically, for $\mathrm{C} 1$, except for the characteristic wide silica bands, the weak bands at 930 and $470 \mathrm{~cm}^{-1}$ were indications of calcium and/or calciummagnesium silicate phases [58,95-97]. For $\mathrm{C} 2$, the main crystalline phase identified by the FTIR spectrum was that of diopside $\left(\mathrm{CaMg}\left(\mathrm{Si}_{2} \mathrm{O}_{6}\right)\right)$, because of the bands at 958,670 and $632 \mathrm{~cm}^{-1}$. Also, the bands at 690 and $745 \mathrm{~cm}^{-1}$ indicated the contribution of magnesium silicate phases such as enstatite $\left(\mathrm{MgSiO}_{3}\right)$. Finally, for $\mathrm{C} 3$, the main crystalline phase identified was that of wollastonite $\left(\mathrm{CaSiO}_{3}\right)$ owing to the bands at 896, 681, 642 and 565 (shoulder) $\mathrm{cm}^{-1}$.

\subsubsection{XRD Results}

The XRD patterns are presented in Figure 3.

From the XRD patterns presented in Figure 3 we observed that there were differences between the samples as they progressively turned from almost amorphous (C1) to more crystalline $(\mathrm{C} 2, \mathrm{C} 3)$. Concerning $\mathrm{C} 1$, except for the calcium siliceous phases, the $\mathrm{Mg}$ incorporation into the silicate lattice was confirmed by the XRD peaks in those areas where broad but characteristic peaks appeared. These peaks were attributed to diopside (\#711497), bredigite (\#36-0399), calcium silicate (\#33-0303, \#45-0156), and calcium-magnesium silicate (\#34-1350, \#89-1484). The diffraction pattern of C2 showed evidence of more crystalline phases, such as diopside (\#86-0932, \#78-13, \#76-0524), enstatite (\#76-0524), merwinite (\#35-0591), hillebrandite (\#42-0538), calcium-magnesium silicate (\#34-1350, \#341216, \#72-1498, \#72-1499), and calcium silicate (\#49-1672, \#33-0303). Concerning C3, the two main crystalline phases were those of wollastonite (\#42-0547, \#72-2297, \#72-2284) and bredigite (\#36-0399). Moreover, as observed in the previous samples, there were more clear indications of diopside (\#83-1818, \#71-1494), calcite (\#83-1762), and magnesium silicate $\left(\mathrm{MgSiO}_{3}\right)$ (\#34-1350, \#87-2037), which again verified the incorporation of $\mathrm{Mg}$ in the calciumsilicate network. The percentage of amorphous phases was calculated to be $78.5 \%$ for $\mathrm{C} 1$, $38.4 \%$ for $\mathrm{C} 2$ and $8.8 \%$ for $\mathrm{C} 3$. Some of the identified phases were not verified from the FTIR analysis, as the synthesized materials consisted mainly of calcium-silicate compounds, which presented a high overlapping in the MIR area. 


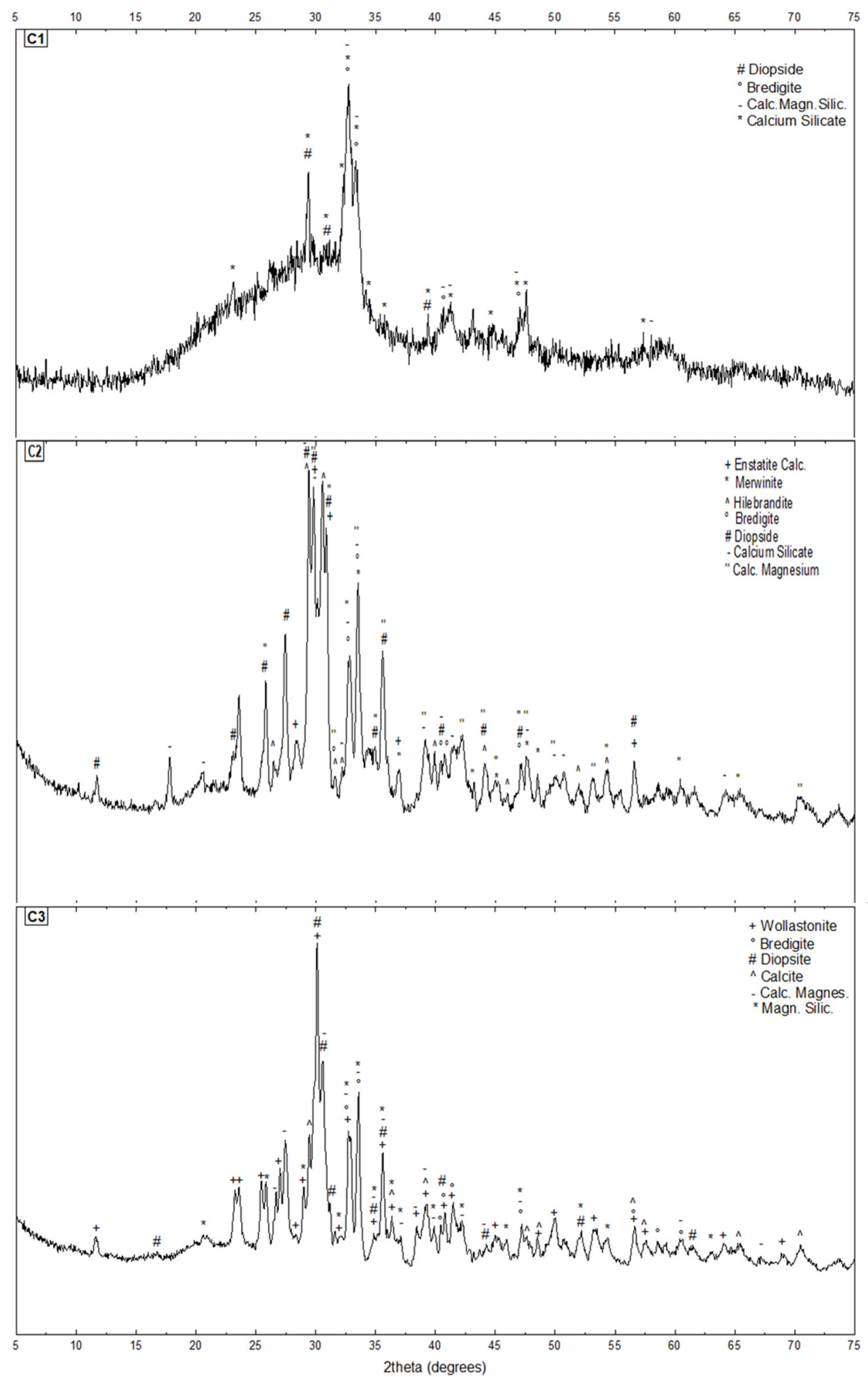

Figure 3. X-ray diffraction patterns of $\mathrm{C} 1\left(835^{\circ} \mathrm{C}\right), \mathrm{C} 2\left(1000{ }^{\circ} \mathrm{C}\right)$, and $\mathrm{C} 3\left(1100{ }^{\circ} \mathrm{C}\right)$ before the immersion in SBF (0 day). 


\subsection{In Vitro Apatite-Forming Ability in Simulated Body Fluid (SBF)}

The results of the FTIR analysis of the samples after immersion in SBF are presented in Figure 4. After the first day of immersion in SBF, the spectrum of $\mathrm{C} 1$ remained unchanged, whereas the spectra of $\mathrm{C} 2$ and $\mathrm{C} 3$ exhibited a weak band at $\sim 580 \mathrm{~cm}^{-1}$, indicating the formation of a precursor calcium-phosphate phase (Ca-P). After the third day of immersion, the characteristic hydroxyapatite (HCAp) bands of bending vibration of phosphate group at 604 and $566 \mathrm{~cm}^{-1}$ were revealed, while in all samples a new weak band at $800 \mathrm{~cm}^{-1}$ was presented, attributed to the symmetrical stretching vibration of the $\mathrm{Si}-\mathrm{O}-\mathrm{Si}$ bond formed by the condensation of silanol groups. The above characteristic bands, attributed to the formation of HCAp, increased in intensity and became more distinct after increasing the immersion time in SBF, indicating that the formation of HAp was time-dependent for all samples. After 10 days of immersion, the sharpening and the shifting of the broad band at $1100-900 \mathrm{~cm}^{-1}$, especially in the spectrum of $\mathrm{C} 1$, indicated the formation of a thick HAp layer.

This was further confirmed by the following XRD patterns of the samples after their immersion in SBF for 0, 3, 5, and 10 days (Figure 5), and SEM images collected after the immersion in SBF for 0 day (Figure 6) and 3, 5, and 10 days (Figure 7). The gradual intensity of the hydroxyapatite peaks-which increased at around $32^{\circ} 2 \theta-$ was indicative of its progressive formation on the surface of the samples, while its onset started at $72 \mathrm{~h}$ for all nanobioceramics. After $72 \mathrm{~h}$ of immersion, the high amount of amorphous phase was decreased in all the samples, while the HAp and calcium-phosphate percentage calculated by Rietveld analysis increased. More specifically, concerning C 3 , all the identified crystalline phases of calcite, magnesium silicate, diopside and wollastonite were gradually decreased as hydroxyapatite crystallized. Hydroxyapatite percentages were $16.0 \%$ at the 3rd day of immersion, $71.1 \%$ at the 5 th, and $76.1 \%$ after 10 days of immersion. Similarly, for $\mathrm{C} 2$ at the 3rd day of immersion hydroxyapatite was $29.6 \%$, at the 5 th day $32.6 \%$, and at the 10th day $80.1 \%$. Concerning C1, the percentages of hydroxyapatite varied from $64.3 \%$ at the 3 rd day to $78.8 \%$ at the 5 th day and $83.4 \%$ for the 10 th day.
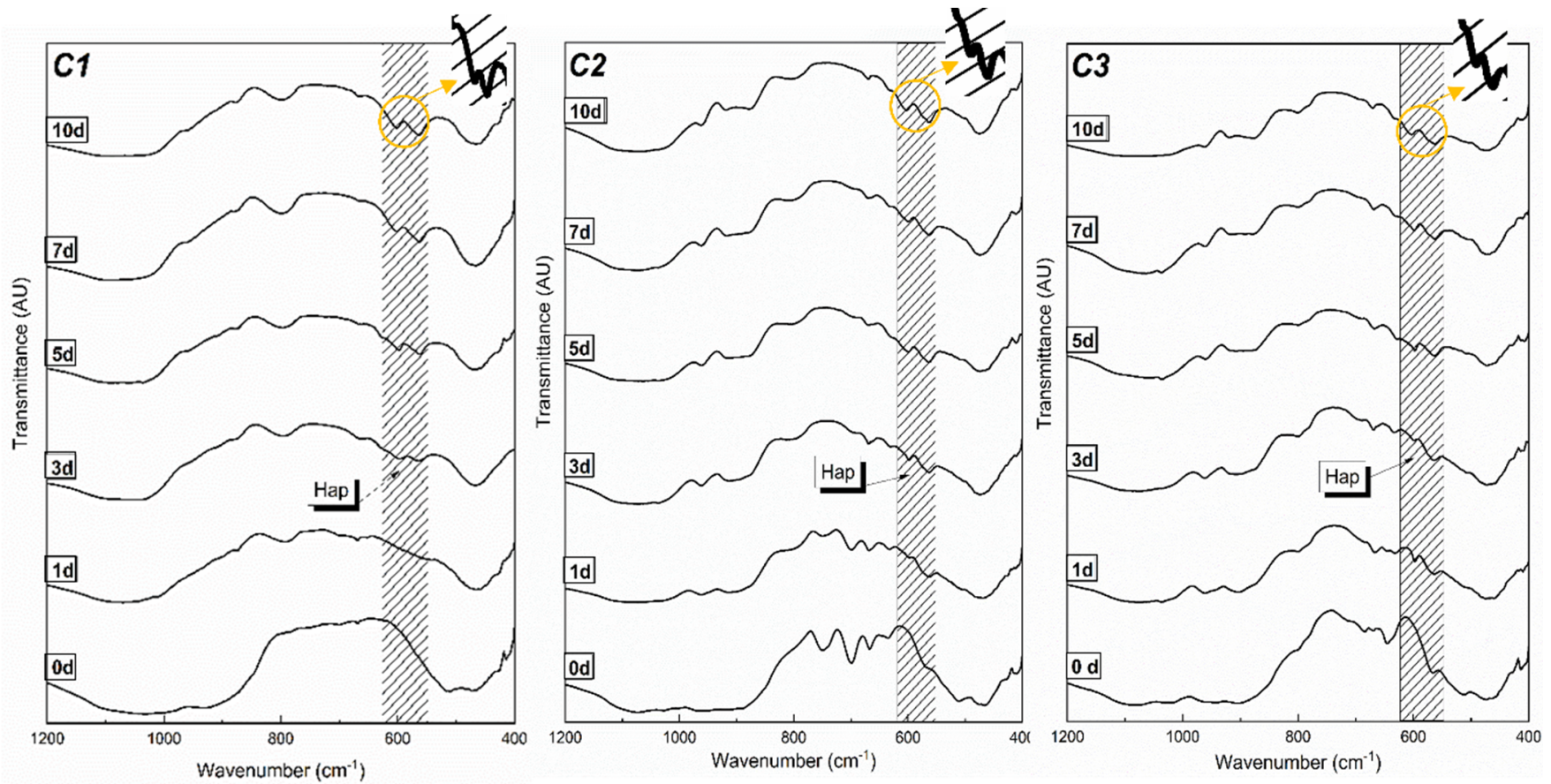

Figure 4. FTIR spectra of all heated samples before and after 1, 3, 5, 7, and 10 days in SBF. The yellow circle with arrow in the spectra of samples after 10 days immersion in SBF indicates the higher magnification of the area with the double peak at 604 and $566 \mathrm{~cm}^{-1}$ of the apatite formation. 


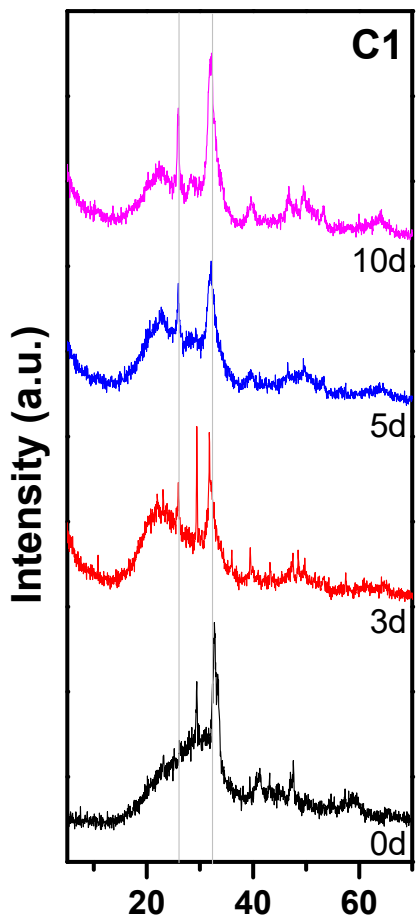

Angle 2-Theta $\left({ }^{\circ}\right)$

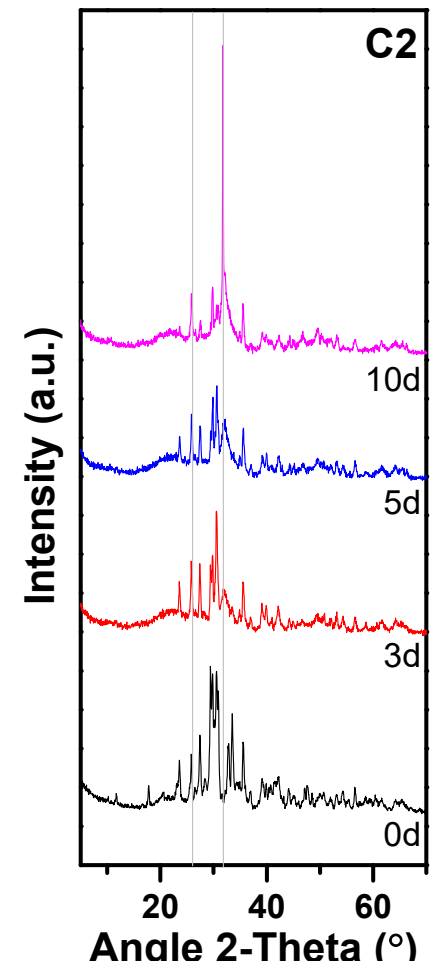

Angle 2-Theta $\left({ }^{\circ}\right)$

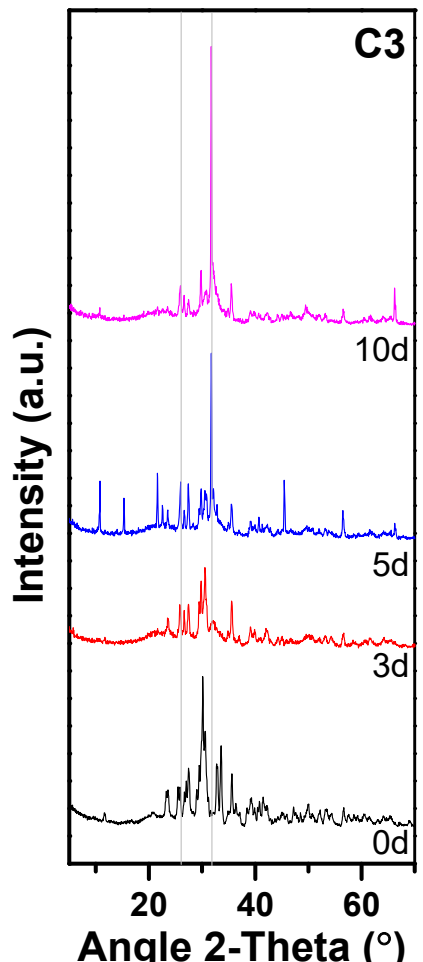

Angle 2-Theta $\left({ }^{\circ}\right)$

Figure 5. XRD patterns of all heated samples before and after 3, 5, and 10 days in SBF.

C1

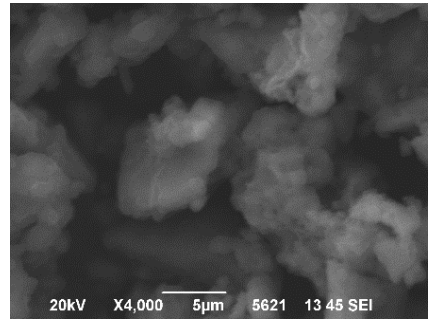

(a)

C2

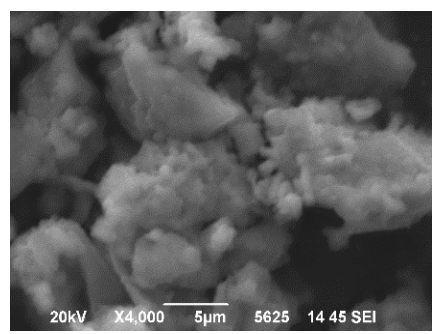

(d)

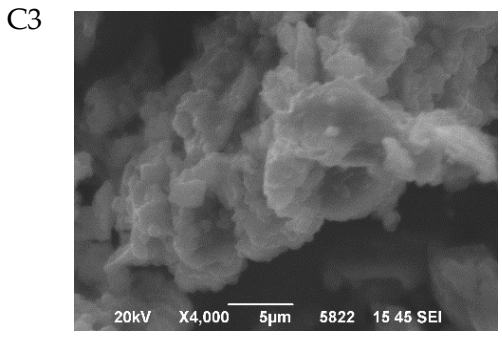

(g)

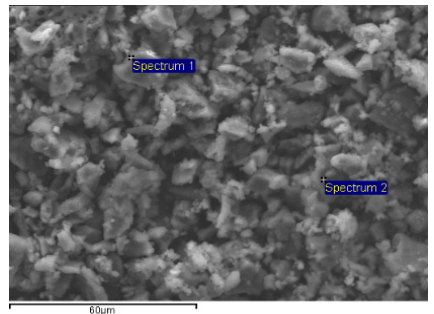

(b)

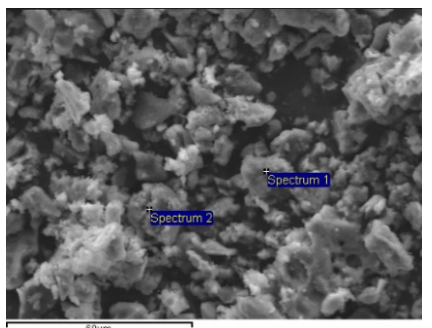

(e)

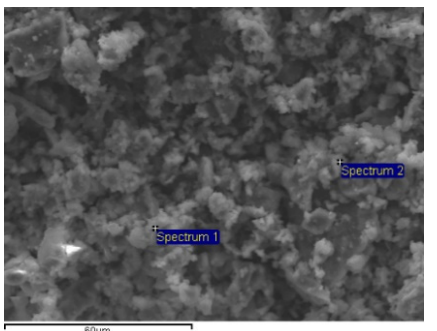

(h)

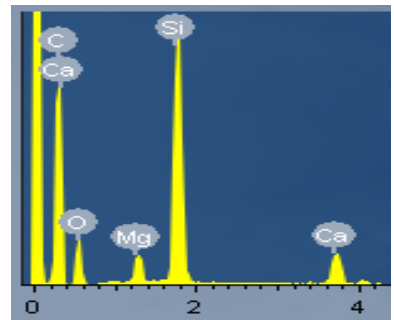

(c)

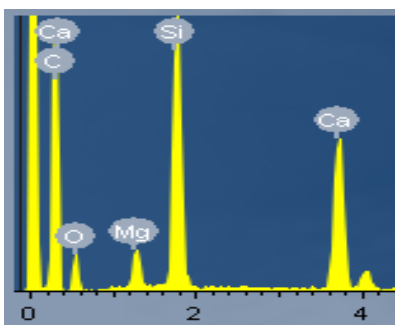

(f)

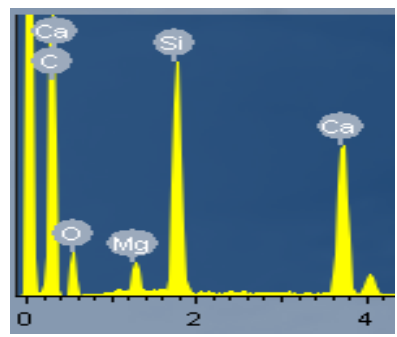

(i)

Figure 6. SEM-EDS analysis of the samples before the immersion in SBF (0 day): (a,d,g) SEM microphotographs, (b,e,h) microphotograph of backscattered electrons, $(\mathbf{c}, \mathbf{f}, \mathbf{i})$ indicative EDS spectra (spectrum 1 in figures $\mathbf{b}, \mathbf{e}, \mathbf{h}$ ) of each sample. 
C1
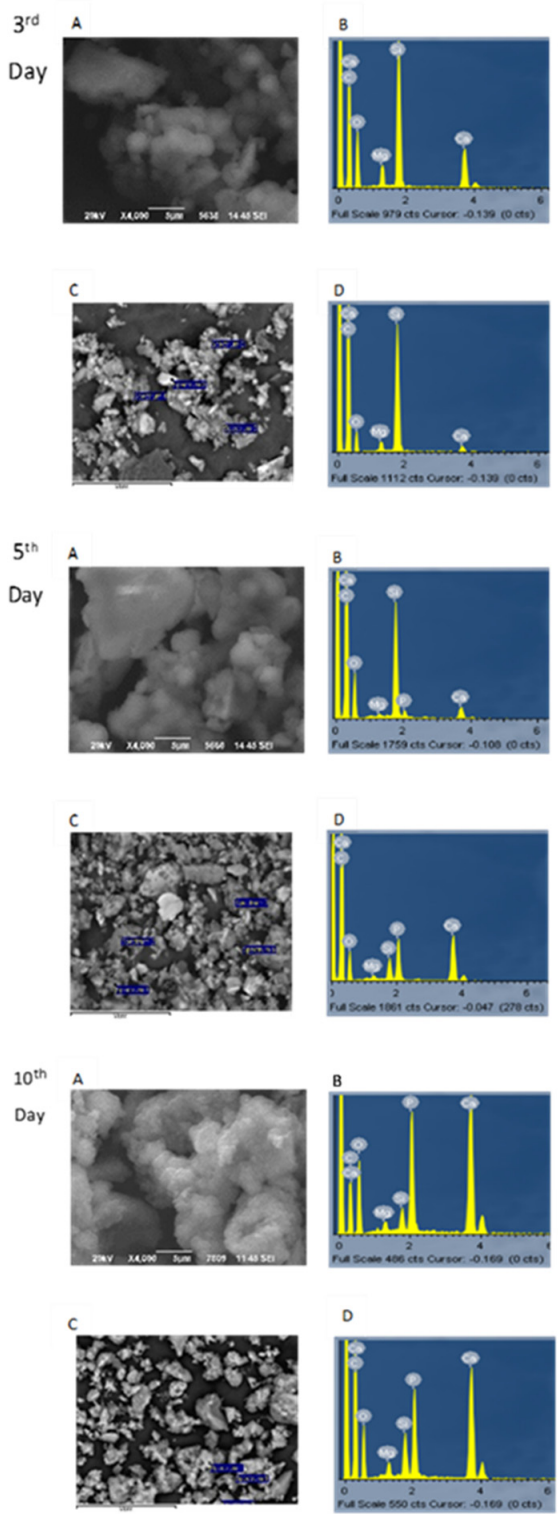
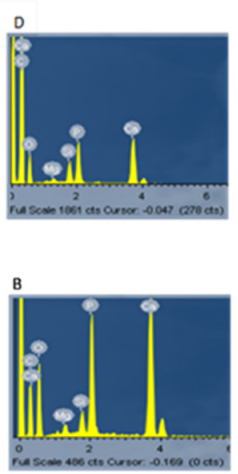

$\mathrm{C} 2$
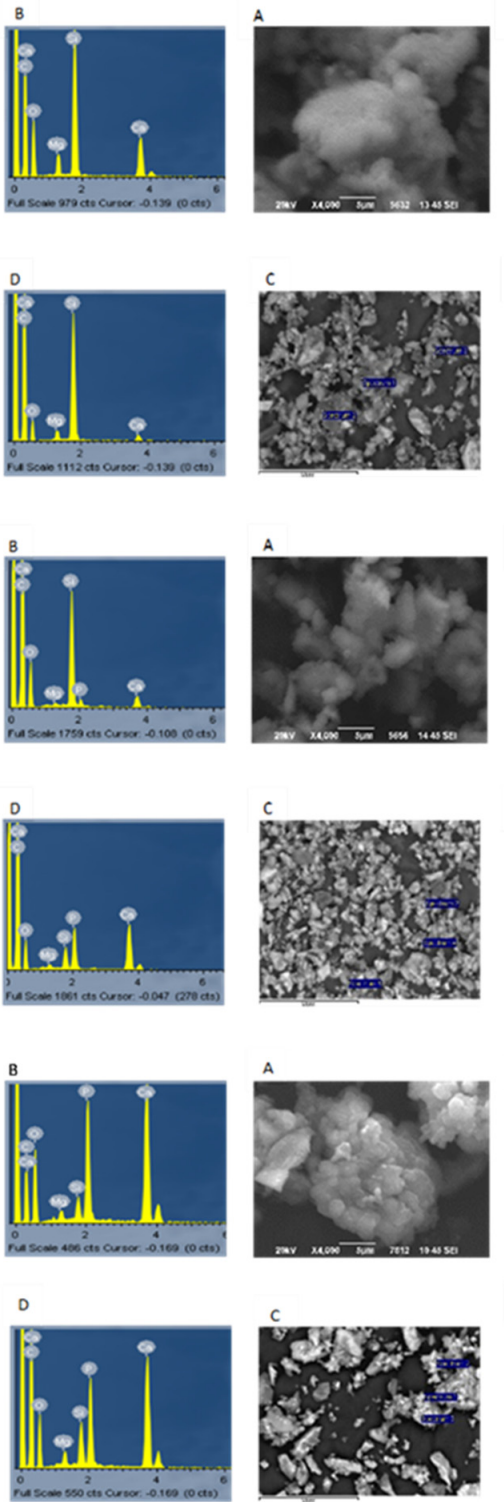
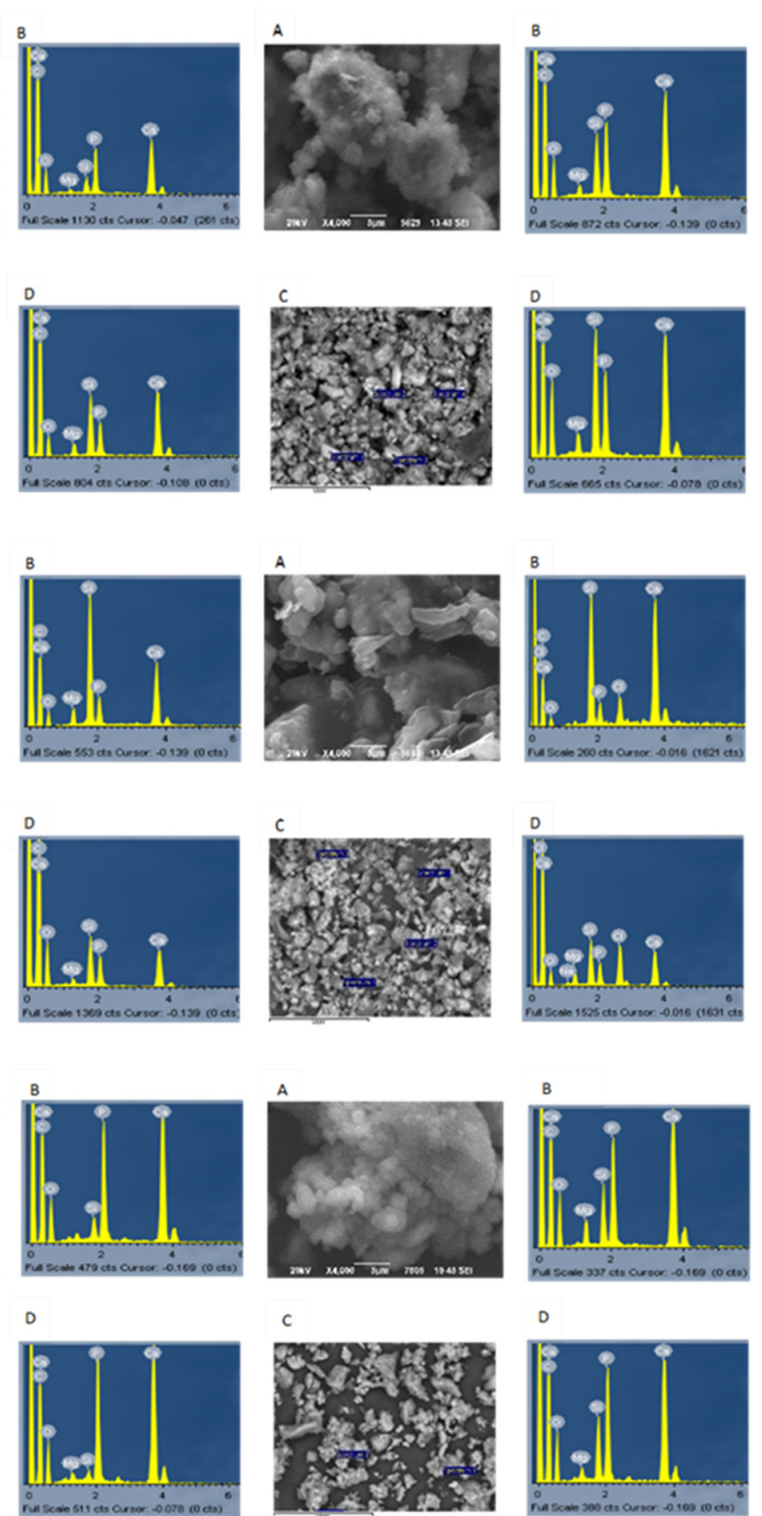

Figure 7. (A) SEM microphotographs of the $C 1, C 2$, and $C 3$ samples after the immersion in SBF $(3,5,10$ days), (B-D) EDS spectra from two different regions (spectrum 1,2) of each sample.

\subsection{Mitochondrial Activity-MTT Assay}

MTT assay results confirmed nontoxic biological behavior in most cases (Figure 8). Although at day 1 a decrease in cell proliferation was observed, indicating a mild cytotoxicity even at the lower concentration, at days 3 and 5 this result was compensated. At day 3 a statistically significant increase in mitochondrial activity $(p<0.01)$ and consequent cell proliferation was presented for $\mathrm{C} 1$, while a minor increase was reported for $\mathrm{C} 2$ and C3. The MTT assay performed with higher concentration eluates $(250 \mu \mathrm{g} / \mathrm{mL})$ revealed a nontoxic biological behavior for all tested materials as verified by the comparable values between tested and control groups. At day 5, an increase in cell proliferation was reported for the $\mathrm{C} 1$ group for both concentrations, while $\mathrm{C} 2$ presented comparable values to control. A statistically significant decrease in cell proliferation for the $\mathrm{C} 3$ higher concentration group compared to the $\mathrm{C} 3$ lower concentration group was recorded $(p<0.01)$ at the two examined time points (day 3, day 5), indicating a dose-dependent cytotoxicity in this group. Overall, 
we support that the MTT assay results confirmed a nontoxic biological behavior for all tested bioceramic materials (C1, C2, and C3) at the lower concentration $(125 \mu \mathrm{g} / \mathrm{mL})$.

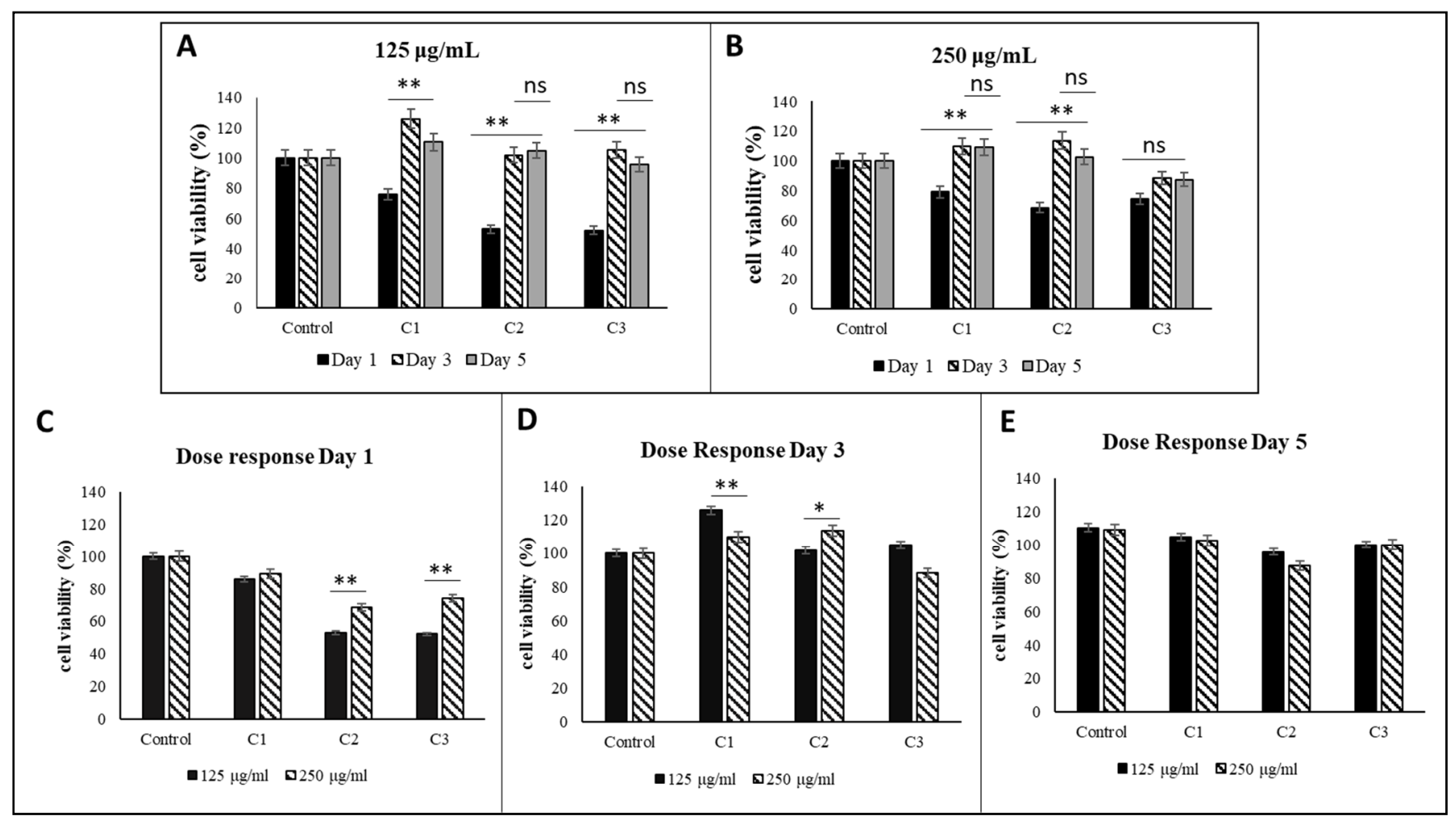

Figure 8. Results of cellular vitality-mitochondrial activity of biomaterials $C 1, C 2, C 3$. (A,B) present differences among groups at low (A) and high (B) concentrations, while (C,D) present differences at day $3(\mathbf{C})$ and day 5 (E) of cell culture. $\left({ }^{*} p<0.05, * * p<0.01\right)$.

\subsection{Antibacterial Assay}

The results of the growth experiments for C1, C2, and C3 are presented in Table 1. Maximum growth rates are given in the form of the ratio between the test compound and the control, rather than as absolute values.

Table 1. Effect of compounds C1, C2, and C3 (0.5 g/L) on the maximum growth rate of seven food-related bacteria as determined by optical density measurements in the Bioscreen $\mathrm{C}$ instrument.

\begin{tabular}{|c|c|c|c|c|c|c|}
\hline \multirow[b]{2}{*}{ Bacterium } & \multicolumn{2}{|c|}{ Compound $\mathrm{C} 1$} & \multicolumn{2}{|c|}{ Compound C2 } & \multicolumn{2}{|c|}{ Compound C3 } \\
\hline & $\begin{array}{c}\text { Ratio } \\
\text { Test: Control }\end{array}$ & $t$ Test ${ }^{1}$ & $\begin{array}{c}\text { Ratio } \\
\text { Test: Control }\end{array}$ & $t$ Test $^{1}$ & $\begin{array}{c}\text { Ratio } \\
\text { Test: Control }\end{array}$ & $t$ Test $^{1}$ \\
\hline Bacillus cereus & 0.86 & 0.001 & 0.87 & 0.001 & 0.87 & 0.001 \\
\hline Staphylococcus aureus & 0.83 & 0.049 & 0.88 & 0.096 & 0.86 & 0.071 \\
\hline Listeria monocytogenes & 1.01 & 0.932 & 1.00 & 0.987 & 0.90 & 0.165 \\
\hline Escherichia coli & 0.97 & 0.238 & 1.03 & 0.226 & 0.94 & 0.071 \\
\hline $\begin{array}{l}\text { Salmonella enterica ser. } \\
\text { Typhimurium }\end{array}$ & 0.79 & 0.095 & 0.91 & 0.011 & 0.97 & 0.235 \\
\hline $\begin{array}{c}\text { Salmonella enterica ser. } \\
\text { Enteritidis }\end{array}$ & 0.90 & 0.013 & 0.81 & 0.000 & 0.87 & 0.000 \\
\hline Pseudomonas aeruginosa & 0.93 & 0.000 & 0.89 & 0.002 & 0.97 & 0.234 \\
\hline
\end{tabular}

\footnotetext{
${ }^{1} t$ test of normalized control data versus normalized test data.
} 
A large degree of inhibition was not observed in any of the bacteria when challenged with any of the three antimicrobial compounds. Statistically significant $(p<0.05)$ decreases in growth rate were observed in B. cereus and S. enterica ser. Enteritidis with all three compounds, and in S. aureus, S. enterica ser. Typhimurium and P. aeruginosa with one or two of the compounds. However, the largest reduction in growth rate was to $83 \%$ of the control value, so the biological significance of the small degrees of inhibition observed is very limited. Large significant increases in lag phase or decreases in maximum optical density were not observed with any combination of bacteria and antimicrobials (data not shown).

\subsection{Oxidative Activity of Bioactive Glass Nanoceramics}

To gain further knowledge about the role of ROS production in gingival human fibroblasts after contact with the synthesized nanomaterials, their oxidative activity was determined by the fluorescent method. In Figure 9, a significant increase in ROS production after treatment with all the tested nanomaterials was observed when compared with the untreated cells (control) $(p<0.01)$.

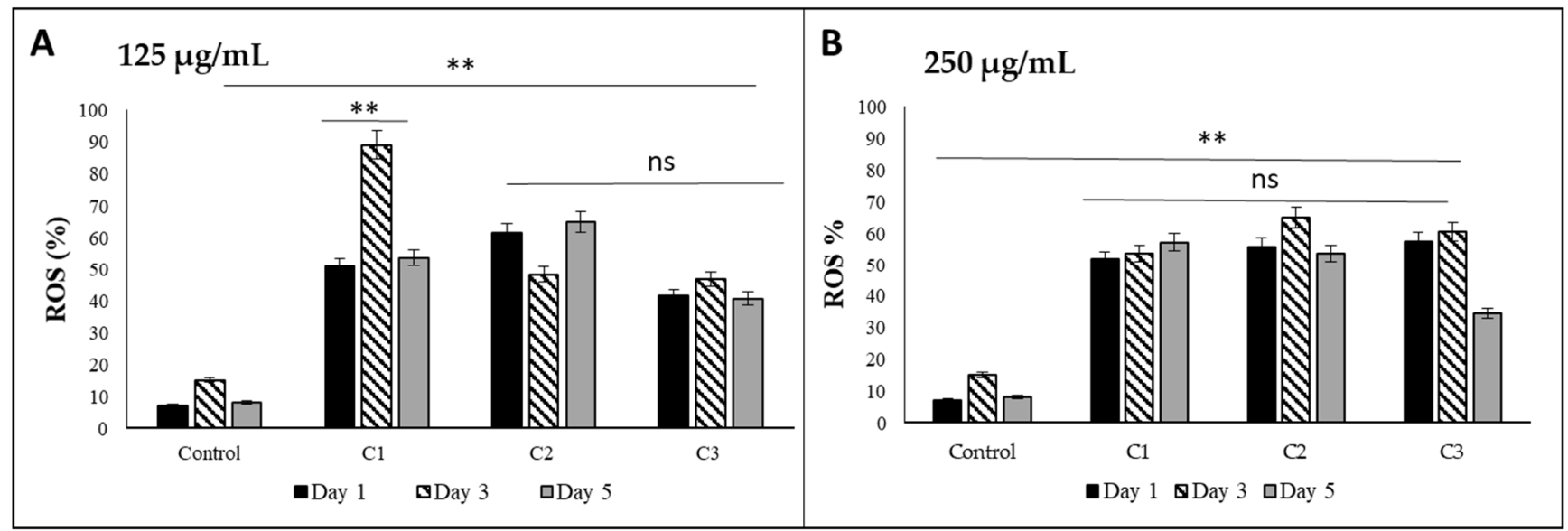

Figure 9. ROS production in gingival human fibroblasts after incubation for 1,3 , and 5 days with the newly synthesized nanomaterials in different concentrations ((A) 125 and (B) $250 \mu \mathrm{g} / \mathrm{mL}) .\left({ }^{* *} p<0.01\right)$.

In details, Figure 9A shows that $\mathrm{C} 1$ induced the higher increase in ROS in the lowest tested concentration $(125 \mu \mathrm{g} / \mathrm{mL})(p<0.01)$ after 3 days of incubation while $\mathrm{C} 2$ and C3 did not present any significant difference between the tested time points. Furthermore, the presence of ROS was observed at all time points; however, fluctuations among different materials and incubation times, following the distinct trend on MTT analysis, were observed.

\section{Discussion}

In general, silica-based bioactive materials present high biocompatibility, bioactivity, and positive biological effects of their reaction products after implantation in bone and tissue applications [10,98-100]. They are used in various applications in bone regeneration and drug delivery. They can stimulate biological and molecular mechanisms of the body and regenerate damaged bone tissue. Most bioceramic systems are based on calcium phosphates such as Bioglass $45 \mathrm{~S} 5$ and 1393, hydroxyapatite (HA), and $\beta$-tricalcium phosphate $(\beta-\mathrm{TCP})$, while calcium-silicate ceramics such as akermanite $\mathrm{Ca} 2 \mathrm{Mg}\left(\mathrm{Si}_{2} \mathrm{O}_{7}\right)$ have also shown similar biological behavior and high bioactivity [11,101-103]. Selecting the appropriate chemical composition is important for the design of a bioactive material for bone tissue engineering. Silicon (Si) is an essential trace element involved in metabolic activity as it plays an important role in processes related to bone growth. Calcium (Ca) promotes the proliferation of osteoblasts, their differentiation, and extracellular matrix maturation (ECM) calcification. Finally, magnesium $(\mathrm{Mg})$ is a very important trace element 
in bone metabolism and plays a critical role in cellular differentiation and accelerating bone remodeling (osteoconductivity) [8,20,55-59,104-107].

In the present study the ternary composition $55 \mathrm{SiO}_{2}-35 \mathrm{CaO}-10 \mathrm{MgO}$ (in $\mathrm{mol} \%$ ) was selected for its high content of calcium and magnesium in relation to similar systems that have shown promising results $[58,108]$. This nanobioceramic was synthesized with the sol-gel method for the purpose of being incorporated into biopolymeric implants, possibly enhancing their mechanical properties, but also enabling them to induce osteogenesis and biointegration. Thermal treatment was performed to induce different crystalline phases that could have a positive effect on bioactivity. According to the thermal analysis, C2 and C3 samples were crystalline glass-ceramic materials, while $\mathrm{C} 1$ was primarily amorphous. All materials, regardless of the thermal treatment, consisted of nanoparticles, as was revealed by DLS measurements and TEM analysis presented in a previous study [66]. The thermally treated specimens presented similar bioactive behavior by developing the double peak of apatite even after 3 days of immersion, which agreed with the literature [105,109-113]. The most amorphous material after immersion in SBF revealed a high amount of apatite even from the 3rd day of immersion, while the $\mathrm{C} 2$ and $\mathrm{C} 3$ nanobioceramics, which were more crystalline, presented a gradual increase in hydroxyapatite percentages. An interesting observation was that C3, from even the 5th day of immersion, had a considerably high percentage of hydroxyapatite $(71.1 \%)$, suggesting that the onset and crystallization of hydroxyapatite may be affected by the amount and type of crystalline phases. Despite that, all materials after 10 days of immersion presented similar percentages of hydroxyapatite formation, a finding that supported their potential use as regenerative materials in bone tissue engineering. Goudouri et al. synthesized an Mg-containing silicate glass-ceramic to be used as a scaffold for cementum/alveolar bone regeneration in the system $60 \mathrm{SiO}_{2}-$ $30 \mathrm{CaO}-10 \mathrm{MgO}$ (in $\mathrm{mol} \%$ ) and reported no apatite or calcium-phosphate layer formation even after 10 days in $\mathrm{SBF}$ when the glass was heated to $1050^{\circ} \mathrm{C}$. The findings of the present study suggested that an increased amount of calcium along with a decrease in silica content are necessary for increased bioactivity, especially after high temperature thermal treatment.

Regarding cell viability, variations were observed in mitochondrial activity between the positive control and the tested materials. A significant increase in cell viability was observed for $\mathrm{C} 1$ and $\mathrm{C} 2$ at day 5 of cell culture. Dose and time dependence were observed on cell viability only for $\mathrm{C} 1$, whereas it was not observed for $\mathrm{C} 2$ and $\mathrm{C} 3$. For only C3, there was a time dependence (day 3) on cell viability. Despite minor differences, it can be safely concluded that all concentrations were at nontoxic levels.

Previous studies have shown that degradation of bioceramics may regulate the growth and metabolism of various cells by releasing ions such as $\mathrm{Si}, \mathrm{Ca}, \mathrm{P}$, and $\mathrm{Na}$ into the culture medium. Cell viability has been demonstrated by previous studies revealing that, despite the fact that ions such as $\mathrm{Mg}, \mathrm{Ca}, \mathrm{Na}$, etc., can play an important role in numerous processes related to bone formation, at high doses in the environment they are questionable, because of toxic effects they may induce $[112,114]$. So, it must be ensured that metal ion release dosages are within a range of nontoxic yields in order to ensure cell viability [59,115-117]. The results of the present study confirmed the bioactivity of the produced materials. They supported the finding that bioactive materials present high surface reactivity and allow surface remodeling when they come in contact with fluids such as cell culture medium. In the literature a cascade reaction after immersion of such materials in DMEM has been reported: first, a rapid exchange of alkali ions with hydrogen $\left(\mathrm{H}+\right.$ or $\left.\mathrm{H}_{3} \mathrm{O}+\right)$ occurs, leading consecutively to the formation of a silica-rich surface layer [118]. However, the described burst release of alkali ions leads to a strong increase in local $\mathrm{pH}$, potentially resulting in $\mathrm{pH}$-dependent cytotoxicity [119-122]. This is the reason that preconditioning was proposed as a procedure necessary before cell seeding. It supported that in case of bioglass 45S5-BGbased scaffolds 2 weeks of preconditioning were necessary before cell seeding [123] and $72 \mathrm{~h}$ in $45 \mathrm{~S} 5$ granules. In the present study only $24 \mathrm{~h}$ preconditioning of tested materials in DMEM was performed. Previous studies have shown that cell viability and proliferation in the presence of bioactive ceramics is cell type- and composition-dependent [21,124-131]. 
The amount of $\mathrm{Mg}$ in this study was the smallest in the ternary composition $\left(55 \mathrm{SiO}_{2}{ }^{-}\right.$ $35 \mathrm{CaO}-10 \mathrm{MgO}$ in $\mathrm{mol} \%$ ) compared to silicon and calcium. The investigation of ion release from these nanobioceramics, calculated by inductively coupled plasma spectrometry (ICP), showed that both $\mathrm{Si}^{2+}$ and $\mathrm{Ca}^{2+}$ ion release increased gradually in the first $24 \mathrm{~h}$, whereas $\mathrm{Mg}^{2+}$ ions remained at steady and much lower values. This implied that $\mathrm{Mg}$ remained in the calcium silica network or in the developed crystalline phases [66], and its poor ion release was not sufficient to induce a significant enhancement of cell proliferation [66]. The MTT assay results could be correlated with the ion release during preconditioning. Increased alkali ion release combined with inadequate $\mathrm{Mg}$ ion release could explain the cytotoxicity observed at day 1 in all tested groups [66]. As already mentioned, this cytotoxicity could be characterized as $\mathrm{pH}$-dependent. The range of the time periods for the passivationproposed in other studies concerning bioactive materials-was broad, varying from $1 \mathrm{~h}$ to 24 days [132] and depended on the fluid used and the composition of the material. As cell viability was continuously higher with longer periods of passivation, extended preconditioning may be necessary in order to enhance the biocompatibility of the tested materials. Boccaccini et al. [132] supported the notion that dynamic passivation is an effective way to increase the compatibility of BGs for cell culture settings. In our study a passive preconditioning model was used. A dynamic one could be more effective concerning cell viability even at day 1 . All these different parameters (material, time, fluid, passive or dynamic preconditioning) should be fields for future study, in order to establish the most beneficial preconditioning protocol for the tested materials before cell seeding [133]. However, our results at days 3 and 5 confirmed that the synthesized materials presented a biocompatible behavior, as besides the $\mathrm{pH}$-dependent cytotoxicity at day 1 , an increase in cell viability and proliferation was reported in all tested groups at the time points that followed.

However, various studies have shown that extracts of bioactive glasses and glassceramics can have a limited effect on fibroblast proliferation and that the type of released ions as well as their concentration are critical in monitoring cell response [134-138]. Contrary to bulk materials, the biological response of nanomaterials is highly dependent on their specific surface area [139], environment $\mathrm{pH}$, particle size (nano, micro), pore size, composition, synthesis, and cell type cultures, so it was difficult to compare the present results with previous findings in the literature. In the study of Tavakoli et al. [140], increased genotoxicity was recorded in periodontal fibroblasts when the concentration of bioactive glass nanoparticles in the eluates was higher than $4 \mathrm{mg} / \mathrm{mL}$. In the present study a low concentration of nanobioceramic nanoparticles was used in the eluates $(1 \mathrm{mg} / \mathrm{mL})$, and thus, the ion content of the extracts may not have been adequate to trigger a strong biological effect on cells. Furthermore, the majority of studies with modified calcium-silicate ternary systems have used human mesenchymal stem cells (hMSCs), osteoblasts, or cementoblasts as the main body of research has been devoted to applications of these materials in orthopedics and dentistry for bone regeneration, etc. Future research is needed to evaluate the biological behavior of these materials at higher concentrations and in direct contact with the cells. Despite differences in the effect of ions released from various bioactive materials on cells, a profound effect on the expression of some critical growth factors and important proteins, including the vascular endothelial growth factor, basic fibroblast growth factor, epidermal growth factor, collagen I, and fibronectin has been recorded in most of these studies [119-122,138,141]. These findings elucidated the enormous potential of bioactive glasses and glass-ceramics in soft tissue regeneration and wound healing [141,142]. The nanobioceramics in the present study led to a favorable behavior on gingival fibroblasts, suggesting that they can also be used with promising results in soft tissue regeneration.

The role of reactive oxygen species (ROS) in cellular processes is a critical parameter for the cells' fate. Intracellular ROS generation can be used as an index of mitochondrial alterations and oxidative stress induced by the interaction of cells with biomaterials [143]. An enhanced production of ROS and oxidative damage can disturb mitochondrial function, affecting cell viability $[144,145]$. Also, many studies have shown that active radicals 
(such as $\mathrm{O}^{2-}, \mathrm{H}_{2} \mathrm{O}_{2}$, etc.) are strongly related to the antibacterial properties of materials [146]. By being strong oxidants, some $\mathrm{ROS}$ (such as $\mathrm{OH}, \mathrm{O}^{2-}$ and $\mathrm{H}_{2} \mathrm{O}_{2}$ ) can cause damage to microorganisms, ensuring their destruction, while oxygen radicals can interact with the components of the bacterial cell as well as other cell components (such as mitochondria), causing irreversible changes in their cell-wall structure, which can lead to bacterial death [146-149]. It is well known that the effects of ROS on cellular functions are dose-dependent, because at low levels ROS play a major role in cell survival signaling processes such as proliferation, differentiation, and wound healing through the activation of a number of growth factors. However, high levels of ROS may damage cells because they are injurious to cell survival by causing inflammation, inducing apoptotic pathways, and even leading to cell death [150-153]. For example, Hunang et al. [154] confirmed that mesoporous silica nanoparticles (MSNs) significantly promoted A375 cell proliferation owing to the decrease in endogenous reactive oxygen species in cells. Also, He et al. $[155,156]$ compared mesoporous silica nanoparticles with a covalently grafted drug delivery system exhibiting a remarkable inhibition effect on ROS levels and on the proliferation activity of LX-2 cells in the long term. Furthermore, Asharani et al. [157] showed that Ag-nanoparticles increased the production of ROS in a dose-dependent manner and reduced the ATP content of the cells, which in turn resulted in damage to cell mitochondria and apoptosis at a later stage. Calcium-silicate nanomaterials are capable of provoking an oxidizing effect as they have hydroxyl groups on their surface [101,102,115,158-161]. In the present study, the antibacterial experiments for these materials, showed a weak antibacterial effect, which could not be correlated with the significant increase in ROS levels generated in the presence of nanobioceramic eluates. However, this increase in ROS levels was inadequate to significantly affect mitochondrial activity and induce cytotoxicity in gingival fibroblasts cells. Different antioxidant mechanisms may be implicated in bacteria and cells that need further clarification. Further research work is needed to investigate their oxidative behavior at the level of interaction with cells for prolonged culture times and their capacity to induce osteogenic differentiation of mesenchymal stem cells.

\section{Conclusions}

Crystalline and relatively amorphous nanobioceramics were successfully synthesized by the sol-gel method and subsequently subjected to different thermal treatments. All materials presented apatite formation in SBF and biocompatibility with human periodontal fibroblasts. The similar expressions of ROS in the presence and absence of nanobioceramic eluates was correlated with the limited antibacterial activity of the materials and verified the absence of oxidative stress on cells from the presence of released ions. Nanobioceramics synthesized in the context of this study possess a multitude of attractive physicochemical and biological properties that make them suitable candidates for bone regeneration applications, as fillers in nanocomposite scaffolds, or as grafts in bone cavities and periodontal lesions.

Author Contributions: Conceptualization, E.K.; methodology, A.T., J.R., E.L. (Eleni Likotrafiti), L.P., E.L. (Evgenia Lymperaki) and G.K.P.; validation, K.K., I.T., A.T., E.K., L.M. and K.C.; formal analysis, K.K., I.T. and L.M.; investigation, K.K., I.T. and E.L. (Evgenia Lymperaki); resources, K.C., T.L.; data curation, K.K., J.R., E.L. (Eleni Likotrafiti), L.P., E.L. (Evgenia Lymperaki) and K.C.; writing-original draft preparation, K.K.; writing-review and editing, I.T., A.T., E.K., E.L. (Evgenia Lymperaki) and L.M.; visualization, E.K. and E.L. (Evgenia Lymperaki); supervision, E.L. (Evgenia Lymperaki), K.C. and A.T. All authors have read and agreed to the published version of the manuscript.

Funding: This research received no external funding. 
Institutional Review Board Statement: The study was conducted according to the guidelines of the Declaration of Helsinki, and approved by the Institutional Review Board (or Ethics Committee) of Tissue Engineering Unit of the Department of Prosthodontics, School of Dentistry, Aristotle University of Thessaloniki, Greece (protocol code \#11 and date of approval (23 November 2017).

Acknowledgments: The authors wish to acknowledge the Athina Bakopoulou for the establishment and supply of the human gingival fibroblast cell line used in the present study. Cell culture experiments were performed in the Tissue Engineering Unit of the Department of Prosthodontics, School of Dentistry, Aristotle University of Thessaloniki, Greece. The authors also want to thank Lambrini Malletzidou and Konstantinos Simeonidis for the assistance with XRD measurements and Triantafyllia Zorba for data interpretation of FTIR measurements.

Conflicts of Interest: The authors declare no conflict of interest.

\section{References}

1. Papadopoulou, L.; Kontonasaki, E.; Zorba, T.; Chatzistavrou, X.; Pavlidou, E.; Paraskevopoulos, K.; Sklavounos, S.; Koidis, P. Dental ceramics coated with bioactive glass: Surface changes after exposure in a simulated body fluid under static and dynamic conditions. Phys. Status Solidi 2003, 198, 65-75. [CrossRef]

2. Goudouri, O.M. Solid State Section Novel Bioactive Ceramics for Dental Ourania Menti Goudouri. 2012. Available online: http:/ /ikee.lib.auth.gr/record/129556/files/GRI-2012-8967.pdf (accessed on 4 June 2019).

3. Park, J.B.; Lakes, R.S. Soft Tissue Replacement-I: Sutures, Skin, and Maxillofacial Implants. In Biomaterials; Springer: New York, NY, USA, 2007; pp. 291-329.

4. Gabriel, S.E. Soft Tissue Response to Silicones. In Handbook of Biomaterial Properties; Springer: Boston, MA, USA, $1998 ;$ pp. 556-571.

5. Papynov, E.; Shichalin, O.; Apanasevich, V.; Portnyagin, A.; Yu, M.V.; Yu, B.I.; Merkulov, E.; Kaidalova, T.; Modin, E.; Afonin, I.; et al. Sol-gel (template) synthesis of osteoplastic $\mathrm{CaSiO}_{3} / \mathrm{HAp}$ powder biocomposite: "In vitro" and "in vivo" biocompatibility assessment. Powder Technol. 2020, 367, 762-773. [CrossRef]

6. Apanasevich, V.; Papynov, E.; Plekhova, N.; Zinoviev, S.; Kotciurbii, E.; Stepanyugina, A.; Korshunova, O.; Afonin, I.; Evdokimov, I.; Shichalin, O.; et al. Morphological Characteristics of the Osteoplastic Potential of Synthetic $\mathrm{CaSiO}_{3} / \mathrm{HAp}$ Powder Biocomposite. J. Funct. Biomater. 2020, 11, 68. [CrossRef]

7. Mucalo, M. Hydroxyapatite (HAp) for Biomedical Applications; Elsevier: Amsterdam, The Netherlands, 2015 ; ISBN 9781782420415.

8. Ni, S.; Chang, J. In vitro Degradation, Bioactivity, and Cytocompatibility of Calcium Silicate, Dimagnesium Silicate, and Tricalcium Phosphate Bioceramics. J. Biomater. Appl. 2009, 24, 139-158. [CrossRef]

9. Park, J.B.; Lakes, R.S. Hard Tissue Replacement-I: Long Bone Repair. In Biomaterials; Springer: New York, NY, USA, 2007; pp. 369-394.

10. Beck, G.R.; Ha, S.-W.; Camalier, C.E.; Yamaguchi, M.; Li, Y.; Lee, J.-K.; Weitzmann, M.N. Bioactive silica-based nanoparticles stimulate bone-forming osteoblasts, suppress bone-resorbing osteoclasts, and enhance bone mineral density in vivo. Nanomed. Nanotechnol. Biol. Med. 2012, 8, 793-803. [CrossRef]

11. Chen, Q.Z.; Thompson, I.D.; Boccaccini, A.R. 45S5 Bioglass ${ }^{\circledR}-$ derived glass-ceramic scaffolds for bone tissue engineering. Biomaterials 2006, 27, 2414-2425. [CrossRef]

12. Papynov, E.K.; Shichalin, O.O.; Apanasevich, V.I.; Afonin, I.S.; Evdokimov, I.O.; Mayorov, V.; Portnyagin, A.S.; Agafonova, I.G.; Skurikhina, Y.; Medkov, M.A. Synthetic $\mathrm{CaSiO}_{3}$ sol-gel powder and SPS ceramic derivatives: “In vivo" toxicity assessment. Prog. Nat. Sci. 2019, 29, 569-575. [CrossRef]

13. Papynov, E.K.; Shichalin, O.O.; Buravlev, I.Y.; Belov, A.A.; Portnyagin, A.S.; Mayorov, V.Y.; Merkulov, E.B.; Kaydalova, T.I.; Skurikhina, Y.E.; Turkutyukov, V.B.; et al. $\mathrm{CaSiO}_{3}-\mathrm{HAp}$ Structural Bioceramic by Sol-Gel and SPS-RS Techniques: Bacteria Test Assessment. J. Funct. Bioceram. 2020, 11, 41. [CrossRef]

14. Black, J.; Hastings, G.W. Handbook of Biomaterial Properties; Chapman \& Hall: London, UK, 1998; ISBN 0412603306.

15. Ratner, B.D.; Hoffman, A.S.; Schoen, F.J.; Lemons, J.E. Biomaterials Science: An Introduction to Materials in Medicine; Academic Press: Cambridge, MA, USA, 2013; ISBN 9780123746269.

16. Doostmohammadi, A.; Monshi, A.; Fathi, M.; Braissant, O. A comparative physico-chemical study of bioactive glass and bone-derived hydroxyapatite. Ceram. Int. 2011, 37, 1601-1607. [CrossRef]

17. Gupta, R.; Kumar, A. Bioactive materials for biomedical applications using sol-gel technology. Biomed. Mater. 2008, 3, 034005. [CrossRef]

18. Paulo, C.; Marques, J.; Sequeira, D.; Diogo, P.; Paiva, R.; Palma, P.; Santos, J. Influence of Blood Contamination on Push-Out Bond Strength of Three Calcium Silicate-Based Materials to Root Dentin. Appl. Sci. 2021, 11, 6849. [CrossRef]

19. Lim, M.; Jung, C.; Shin, D.-H.; Cho, Y.-B.; Song, M. Calcium silicate-based root canal sealers: A literature review. Restor. Dent. Endod. 2020, 45, e35. [CrossRef]

20. El-Kady, A.; Farag, M. Bioactive Glass Nanoparticles as a New Delivery System for Sustained 5-Fluorouracil Release: Characterization and Evaluation of Drug Release Mechanism. J. Nanomater. 2015, 2015, 839207. [CrossRef]

21. Mortazavi, V.; Nahrkhalaji, M.M.; Fathi, M.H.; Mousavi, S.B.; Esfahani, B.N. Antibacterial effects of sol-gel-derived bioactive glass nanoparticle on aerobic bacteria. J. Biomed. Mater. Res. Part A 2010, 94, 160-168. [CrossRef] [PubMed] 
22. Jittiarporn, P.; Badilescu, S.; Al Sawafta, M.N.; Sikong, L.; Truong, V.-V. Electrochromic properties of sol-gel prepared hybrid transition metal oxides-A short review. J. Sci. Adv. Mater. Devices 2017, 2, 286-300. [CrossRef]

23. Ullah, M.; Ali, M.E.; Hamid, S.B.A. Surfactant-Assisted Ball Milling: A Novel Route to Novel Materials with Controlled Nanostructure-A Review. Rev. Adv. Mater. Sci. 2014, 37, 1-14.

24. Ramesh, K.T. Nanomaterials. In Nanomaterials; Springer: Boston, MA, USA, 2009; pp. 1-20.

25. Chapelle, A.; Hassani, F.O.; Presmanes, L.; Barnabe, A.; Tailhades, P. $\mathrm{CO}_{2}$ sensing properties of semiconducting copper oxide and spinel ferrite nanocomposite thin film. Appl. Surf. Sci. 2010, 256, 4715-4719. [CrossRef]

26. Ennas, G.; Marongiu, G.; Marras, S.; Piccaluga, G. Mechanochemical Route for the Synthesis of Cobalt Ferrite-Silica and Iron-Cobalt Alloy-Silica Nanocomposites. J. Nanopart. Res. 2004, 6, 99-105. [CrossRef]

27. Clark, A.E.; Hench, L.L.; Paschall, H.A. The influence of surface chemistry on implant interface histology: A theoretical basis for implant materials selection. J. Biomed. Mater. Res. 1976, 10, 161-174. [CrossRef]

28. Rahman, A.; Seth, D.; Mukhopadhyaya, S.K.; Brahmachary, R.L.; Ulrichs, C.; Goswami, A. Surface functionalized amorphous nanosilica and microsilica with nanopores as promising tools in biomedicine. Naturwissenschaften 2009, 96, 31-38. [CrossRef]

29. Decan, N.; Wu, D.; Williams, A.; Bernatchez, S.; Johnston, M.; Hill, M.; Halappanavar, S. Characterization of in vitro genotoxic, cytotoxic and transcriptomic responses following exposures to amorphous silica of different sizes. Mutat. Res. Toxicol. Environ. Mutagen. 2016, 796, 8-22. [CrossRef]

30. Hench, L.L. The story of Bioglass ${ }^{\circledR}$. J. Mater. Sci. Mater. Med. 2006, 17, 967-978. [CrossRef] [PubMed]

31. Barrioni, B.R.; Aline, A.; De Oliveira, R.; Materials, A.S. Biocompatible Glasses; Marchi, J., Ed.; Centro de Ciências Naturais e Humanas Universidade Federal do ABC: Santo André, Brazil, 2016; Volume 53, ISBN 978-3-319-44247-1.

32. Jaganathan, H.; Godin, B. Biocompatibility assessment of Si-based nano- and micro-particles. Adv. Drug Deliv. Rev. 2012, 64, 1800-1819. [CrossRef] [PubMed]

33. Fiocco, L.; Li, S.; Stevens, M.; Bernardo, E.; Jones, J. Biocompatibility and bioactivity of porous polymer-derived Ca-Mg silicate ceramics. Acta Biomater. 2017, 50, 56-67. [CrossRef]

34. Asefa, T.; Tao, Z. Biocompatibility of Mesoporous Silica Nanoparticles. Chem. Res. Toxicol. 2012, 25, 2265-2284. [CrossRef]

35. Eom, H.-J.; Choi, J. Oxidative stress of silica nanoparticles in human bronchial epithelial cell, Beas-2B. Toxicol. Vitr. 2009, 23, 1326-1332. [CrossRef]

36. ECETOC Synthetic Amorphous Silica-ECETOC JACC REPORT No. 51. 2006. Available online: http://www.ecetoc.org/ publication/jacc-report-51-synthetic-amorphous-silica/ (accessed on 15 August 2019).

37. Lin, Y.-S.; Haynes, C. Impacts of Mesoporous Silica Nanoparticle Size, Pore Ordering, and Pore Integrity on Hemolytic Activity. J. Am. Chem. Soc. 2010, 132, 4834-4842. [CrossRef]

38. Razzaboni, B.L.; Bolsaitis, P. Evidence of an oxidative mechanism for the hemolytic activity of silica particles. Environ. Health Perspect. 1990, 87, 337-341. [CrossRef]

39. Bellantone, M.; Coleman, N.J.; Hench, L.L. Bacteriostatic Action of a Novel Four-Componenr Bioactive Glass. J. Biomed. Mater. Res. 2000, 51, 484-490. [CrossRef]

40. Stoor, P.; Söderling, E.; Salonen, J.I. Antibacterial effects of a bioactive glass paste on oral microorganisms. Acta Odontol. Scand. 1998, 56, 161-165. [CrossRef]

41. Rivadeneira, J.; Luz, G.M.; Audisio, M.C.; Mano, J.F.; Gorustovich, A.A. Novel antibacterial bioactive glass nanocomposite functionalized with tetracycline hydrochloride. Biomed. Glas. 2015, 1, 128-135. [CrossRef]

42. Catauro, M.; Raucci, M.G.; De Gaetano, F.; Marotta, A. Antibacterial and bioactive silver-containing $\mathrm{Na}_{2} \mathrm{O} \cdot \mathrm{CaO} \cdot 2 \mathrm{SiO} 2$ glass prepared by sol-gel method. J. Mater. Sci. Mater. Med. 2004, 15, 831-837. [CrossRef]

43. Thrivikraman, G.; Madras, G.; Basu, B. In vitro/In vivo assessment and mechanisms of toxicity of bioceramic materials and its wear particulates. RSC Adv. 2014, 4, 12763-12781. [CrossRef]

44. Marques, A.; Reis, R.L.; Hunt, J. The biocompatibility of novel starch-based polymers and composites: In vitro studies. Biomaterials 2002, 23, 1471-1478. [CrossRef]

45. Doostmohammadi, A.; Monshi, A.; Salehi, R.; Fathi, M.H.; Golniya, Z.; Daniels, A.U. Bioactive glass nanoparticles with negative zeta potential. Ceram. Int. 2011, 37, 2311-2316. [CrossRef]

46. Serrano, E.; Linares, N.; Garcia-Martinez, J.; Berenguer, J.R. Sol-Gel Coordination Chemistry: Building Catalysts from the Bottom-Up. ChemCatChem 2013, 5, 844-860. [CrossRef]

47. Brinker, C.J.; Scherer, G.W. Sol-Gel Science: The Physics and Chemistry of Sol-Gel Processing; Academic Press: Cambridge, MA, USA, 1990; ISBN 0121349705.

48. Xu, S.; Lin, K.; Wang, Z.; Chang, J.; Wang, L.; Lu, J.; Ning, C. Reconstruction of calvarial defect of rabbits using porous calcium silicate bioactive ceramics. Biomaterials 2008, 29, 2588-2596. [CrossRef]

49. Iimori, Y.; Kameshima, Y.; Yasumori, A.; Okada, K. Effect of solid/solution ratio on apatite formation from $\mathrm{CaSiO}_{3}$ ceramics in simulated body fluid. J. Mater. Sci. Mater. Med. 2004, 15, 1247-1253. [CrossRef]

50. Ni, S.; Chang, J.; Chou, L.; Zhai, W. Comparison of osteoblast-like cell responses to calcium silicate and tricalcium phosphate ceramicsin vitro. J. Biomed. Mater. Res. Part B Appl. Biomater. 2007, 80, 174-183. [CrossRef]

51. Bouler, J.-M.; Pilet, P.; Gauthier, O.; Verron, E. Biphasic calcium phosphate ceramics for bone reconstruction: A review of biological response. Acta Biomater. 2017, 53, 1-12. [CrossRef] 
52. Iimori, Y.; Kameshima, Y.; Okada, K.; Hayashi, S. Comparative study of apatite formation on $\mathrm{CaSiO}_{3}$ ceramics in simulated body fluids with different carbonate concentrations. J. Mater. Sci. Mater. Med. 2005, 16, 73-79. [CrossRef]

53. Srinath, P.; Azeem, P.A.; Reddy, K.V. Review on calcium silicate-based bioceramics in bone tissue engineering. Int. J. Appl. Ceram. Technol. 2020, 17, 2450-2464. [CrossRef]

54. Ni, S.; Chang, J.; Chou, L. In vitro studies of novel $\mathrm{CaO}-\mathrm{SiO}_{2}-\mathrm{MgO}$ system composite bioceramics. J. Mater. Sci. Mater. Med. 2008, 19, 359-367. [CrossRef]

55. Liu, C.C. Magnesium Directly Stimulates Osteoblast Proliferation. J. Bone Miner. Res. 1988, 3, S104.

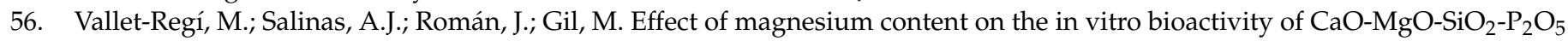
sol-gel glasses. J. Mater. Chem. 1999, 9, 515-518. [CrossRef]

57. Chen, X.; Ou, J.; Kang, Y.; Huang, Z.; Zhu, H.; Yin, G.; Wen, H. Synthesis and characteristics of monticellite bioactive ceramic. J. Mater. Sci. Mater. Electron. 2008, 19, 1257-1263. [CrossRef] [PubMed]

58. Goudouri, O.-M.; Vogel, C.; Grünewald, A.; Detsch, R.; Kontonasaki, E.; Boccaccini, A.R. Sol-gel processing of novel bioactive Mg-containing silicate scaffolds for alveolar bone regeneration. J. Biomater. Appl. 2016, 30, 740-749. [CrossRef]

59. Bakopoulou, A.; Papachristou, E.; Bousnaki, M.; Hadjichristou, C.; Kontonasaki, E.; Theocharidou, A.; Papadopoulou, L.; Kantiranis, N.; Zachariadis, G.; Leyhausen, G.; et al. Human treated dentin matrices combined with Zn-doped, Mg-based bioceramic scaffolds and human dental pulp stem cells towards targeted dentin regeneration. Dent. Mater. 2016, 32, e159-e175. [CrossRef]

60. Chen, I.; Salhab, I.; Setzer, F.; Kim, S.; Nah, H.-D. A New Calcium Silicate-based Bioceramic Material Promotes Human Osteoand Odontogenic Stem Cell Proliferation and Survival via the Extracellular Signal-regulated Kinase Signaling Pathway. J. Endod. 2016, 42, 480-486. [CrossRef]

61. Xia, L.; Zhang, Z.; Chen, L.; Zhang, W.; Zeng, D.; Zhang, X.; Chang, J.; Jiang, X. Proliferation and osteogenic differentiation of human periodontal ligament cells on akermanite and $\beta$-TCP bioceramics. Eur. Cells Mater. 2011, 22, 68-83. [CrossRef]

62. Zhou, Y.; $\mathrm{Wu}, \mathrm{C}$; $\mathrm{Xiao}, \mathrm{Y}$. The stimulation of proliferation and differentiation of periodontal ligament cells by the ionic products from $\mathrm{Ca}_{7} \mathrm{Si}_{2} \mathrm{P}_{2} \mathrm{O}_{16}$ bioceramics. Acta Biomater. 2012, 8, 2307-2316. [CrossRef]

63. Zhou, Y.; Wu, C.; Zhang, X.; Han, P.; Xiao, Y. The ionic products from bredigite bioceramics induced cementogenic differentiation of periodontal ligament cells via activation of the Wnt/ $\beta$-catenin signalling pathway. J. Mater. Chem. B 2013, 1, 3380-3389. [CrossRef]

64. Elsayed, H.; Romero, A.R.; Ferroni, L.; Gardin, C.; Zavan, B.; Bernardo, E. Bioactive Glass-Ceramic Scaffolds from Novel 'Inorganic Gel Casting' and Sinter-Crystallization. Materials 2017, 10, 171. [CrossRef]

65. Srinath, P.; Azeem, P.A.; Reddy, K.V.; Chiranjeevi, P.; Bramanandam, M.; Rao, R.P. A novel cost-effective approach to fabricate diopside bioceramics: A promising ceramics for orthopedic applications. Adv. Powder Technol. 2021, 32, 875-884. [CrossRef]

66. Tsamesidis, I.; Kazeli, K.; Lymperaki, E.; Pouroutzidou, G.K.; Oikonomou, I.M.; Komninou, P.; Zachariadis, G.; Reybier, K.; Pantaleo, A.; Kontonasaki, E. Effect of Sintering Temperature of Bioactive Glass Nanoceramics on the Hemolytic Activity and Oxidative Stress Biomarkers in Erythrocytes. Cell. Mol. Bioeng. 2020, 13, 201-218. [CrossRef]

67. Stober, W.; Fink, A.; Bohn, E. Controlled Growth of Monodisperse Silica Spheres in the Micron Size Range. J. Colloid Interface Sci. 1968, 26, 62-69. [CrossRef]

68. Greasley, S.L.; Page, S.J.; Sirovica, S.; Chen, S.; Martin, R.; Riveiro, A.; Hanna, J.V.; Porter, A.E.; Jones, J.R. Controlling particle size in the Stöber process and incorporation of calcium. J. Colloid Interface Sci. 2016, 469, 213-223. [CrossRef]

69. Kokubo, T.; Ito, S.; Huang, Z.T.; Hayashi, T.; Sakka, S.; Kitsugi, T.; Yamamuro, T. Ca, P-rich layer formed on high-strength bioactive glass-ceramic A-W. J. Biomed. Mater. Res. 1990, 24, 331-343. [CrossRef]

70. Tsamesidis, I.; Pouroutzidou, G.K.; Lymperaki, E.; Kazeli, K.; Lioutas, C.B.; Christodoulou, E.; Kontonasaki, E. Effect of ion doping in silica-based nanoparticles on the hemolytic and oxidative activity in contact with human erythrocytes. Chem.-Biol. Interact. 2020, 318, 108974. [CrossRef]

71. Saravanan, P.; Raja, M.M.; Gopalan, R.; Rao, N.R.; Suresh, K.; Rao, D.S.; Chandrasekaran, V. Structural and Mössbauer studies on mechanical milled SmCo5/ $\alpha$-Fe nanocomposite magnetic powders. Intermetallics 2008, 16, 636-641. [CrossRef]

72. Lu, K.; Zhang, H.Y.; Zhong, Y.; Fecht, H.J. Grain Size Dependence of Mechanical Properties in Nanocrystalline Selenium. J. Mater. Res. 1997, 12, 923-930. [CrossRef]

73. Hench, L.L.; Ulrich, D.R.; University of Florida, Department of Materials Science and Engineering; University of Florida, College of Engineering. Ultrastructure Processing of Ceramics, Glasses, and Composites; Wiley: Hoboken, NJ, USA, 1984 ; ISBN 0471896691.

74. Zhou, L.; Zhang, H.; Zhang, Z. Homogeneous nanoparticle dispersion prepared with impurity-free dispersant by the ball mill technique. Particuology 2013, 11, 441-447. [CrossRef]

75. Salavati-Niasari, M.; Javidi, J.; Dadkhah, M. Ball Milling Synthesis of Silica Nanoparticle from Rice Husk Ash for Drug Delivery Application. Salavati-Niasari M, Javidi J, Dadkhah M. Ball milling synthesis of silica nanoparticle from rice husk ash for drug delivery application. Comb. Chem. High Throughput Screen. 2013, 16, 458-462. [CrossRef]

76. Mattos, B.; Rojas, O.; Magalhaes, W. Biogenic $\mathrm{SiO}_{2}$ in colloidal dispersions via ball milling and ultrasonication. Powder Technol. 2016, 301, 58-64. [CrossRef]

77. Díaz-Flores, L.L.; Pérez-Bueno, J.J.; Espinoza-Beltrán, F.J.; Pérez-Robles, J.F.; Ramírez-Bon, R.; Vorobiev, Y.V.; González-Hernández, J. Effect of gelation and ball milling on the optical absorption and emission of macrilon yellow dye molecules trapped in silica prepared by the sol-gel method. Microelectron. Eng. 2000, 51, 659-666. [CrossRef] 
78. Tsamesidis, I.; Kazeli, K.; Pouroutzidou, G.; Reybier, K.; Pantaleo, A.; Lymperaki, E.; Kontonasaki, E. Evaluation of Hemolytic Activity and Oxidative Stress Biomarkers in Erythrocytes after Exposure to Bioactive Glass Nanoceramics. Beilstein Arch. 2019, 1, 201985. [CrossRef]

79. PC Powder Diffraction Files. 2003. Joint Committee on Powder Diffraction Standards. International Centre for Diffraction Data (PC PDF, JCPDS-ICDD). Available online: https:/ / www.icdd.com/ (accessed on 5 April 2019).

80. Kokubo, T.; Kushitani, H.; Sakka, S.; Kitsugi, T.; Yamamuro, T. Solutions able to reproduce in vivo surface-structure changes in bioactive glass-ceramic A-W3. J. Biomed. Mater. Res. 1990, 24, 721-734. [CrossRef]

81. Hench, L.L.; Wang, S.H. The sol-gel glass transformation of silica. Phase Transit. 1990, 24-26, 785-834. [CrossRef]

82. Hench, L.L.; West, J.K. The sol-gel process. Chem. Rev. 1990, 90, 33-72. [CrossRef]

83. Goudouri, O.M.; Kontonasaki, E.; Theocharidou, A.; Papadopoulou, L.; Kantiranis, N.; Chatzistavrou, X.; Koidis, P.; Paraskevopoulos, K.M. Investigation of the Bioactivity of Dental Ceramic/Bioactive Glass Composites Prepared by the Sol Gel Route. Mater. Chem. Phys. 2011, 125, 309-313. [CrossRef]

84. Hollinger, J.O. Bone Tissue Engineering; CRC Press: Boca Raton, FL, USA, 2005; ISBN 9780849316210.

85. L'vov, B.V. Decomposition Mechanism; Springer: Berlin/Heidelberg, Germany, 2007; pp. 11-32.

86. Ettarh, C.; Galwey, A.K. A kinetic and mechanistic study of the thermal decomposition of calcium nitrate. Thermochim. Acta 1996, 288, 203-219. [CrossRef]

87. Viczián, I. Földvári, Mária: Handbook of the thermogravimetric system of minerals and its use in geological practice. Central Eur. Geol. 2013, 56, 397-400. [CrossRef]

88. Mirhadi, S.; Tavangarian, F.; Emadi, R. Synthesis, characterization and formation mechanism of single-phase nanostructure bredigite powder. Mater. Sci. Eng. C 2012, 32, 133-139. [CrossRef]

89. Goudouri, O.M.; Kontonasaki, E.; Chatzistavrou, X.; Papadopoulou, L.; Koidis, P.; Paraskevopoulos, K.M. Investigation of the Bioactivity of Dental Ceramic/Bioactive Glass Composites Prepared by the Sol Gel Route. Key Eng. Mater. 2009, 396-398, 119-122. [CrossRef]

90. Zhong, J.; Greenspan, D.C. Processing and properties of sol-gel bioactive glasses. J. Biomed. Mater. Res. 2000, 53, 694-701. [CrossRef]

91. Tomozawa, M.; Hong, J.-W.; Ryu, S.-R. Infrared (IR) investigation of the structural changes of silica glasses with fictive temperature. J. Non-Cryst. Solids 2005, 351, 1054-1060. [CrossRef]

92. Farmer, V.C. The Anhydrous Oxide Minerals. In Infrared Spectra of Minerals in Mineralogical, Society Monograph 4; Mineralogical Society: London, UK, 1974; pp. 183-204.

93. Gervais, F.; Blin, A.; Massiot, D.; Coutures, J.; Chopinet, M.; Naudin, F. Infrared reflectivity spectroscopy of silicate glasses. J. Non-Crystalline Solids 1987, 89, 384-401. [CrossRef]

94. Smith, B.C. Infrared Spectral Interpretation: A Systematic Approach; CRC Press: Boca Raton, FL, USA, 1999.

95. Lenza, R.; Vasconcelos, W. Preparation of silica by sol-gel method using formamide. Mater. Res. 2001, 4, 189-194. [CrossRef]

96. Simon, I.; McMahon, H.O. Study of Some Binary Silicate Glasses by Means of Reflection in Infrared. J. Am. Ceram. Soc. 1953, 36, 160-164. [CrossRef]

97. Gutzow, I.; Schmelzer, J. The Vitreous State: Thermodynamics, Structure, Rheology, and Crystallization; Springer: Berlin/Heidelberg, Germany, 2013; ISBN 9783642346330.

98. Bonfield, W.; Hastings, G.W.; Tanner, K.E. International Symposium on Ceramics in Medicine (4th: 1991: London, G.B. Bioceramics. Volume 4. In Proceedings of the 4th International Symposium on Ceramics in Medicine, London, UK, 11-13 September 1991; Butterworth Heinemann: Oxford, UK, 1991; Volume 4, ISBN 9781483193649.

99. Goudouri, O.M.; Kontonasaki, E.; Theocharidou, A.; Papadopoulou, L.; Chatzistavrou, X.; Koidis, P.; Paraskevopoulos, K.M. In Vitro Bioactivity Studies of Sol-Gel Derived Dental Ceramics/Bioactive Glass Composites in Periodically Renewed Biomimetic Solution. Bioceram. Dev. Appl. 2011, 1, 1-4. [CrossRef]

100. Salinas, A.J.; Vallet-Regí, M. Bioactive ceramics: From bone grafts to tissue engineering. RSC Adv. 2013, 3, 11116-11131. [CrossRef]

101. Hafezi-Ardakani, M.; Moztarzadeh, F.; Rabiee, M.; Talebi, A.R. Synthesis and characterization of nanocrystalline merwinite $\left(\mathrm{Ca}_{3} \mathrm{Mg}\left(\mathrm{SiO}_{4}\right)_{2}\right)$ via sol-gel method. Ceram. Int. 2011, 37, 175-180. [CrossRef]

102. Rahmati, M.; Fathi, M.; Ahmadian, M. Preparation and structural characterization of bioactive bredigite $\left(\mathrm{Ca}_{7} \mathrm{MgSi}_{4} \mathrm{O}_{16}\right)$ nanopowder. J. Alloys Compd. 2018, 732, 9-15. [CrossRef]

103. Hou, X.; Yin, G.; Chen, X.; Liao, X.; Yao, Y.; Huang, Z. Effect of akermanite morphology on precipitation of bone-like apatite. Appl. Surf. Sci. 2011, 257, 3417-3422. [CrossRef]

104. Wu, C.; Chang, J.; Zhai, W.; Ni, S. A novel bioactive porous bredigite $\left(\mathrm{Ca}_{7} \mathrm{MgSi}_{4} \mathrm{O}_{16}\right)$ scaffold with biomimetic apatite layer for bone tissue engineering. J. Mater. Sci. Mater. Med. 2007, 18, 857-864. [CrossRef]

105. Prabhu, M.; Kavitha, K.; Manivasakan, P.; Rajendran, V.; Kulandaivelu, P. Synthesis, characterization and biological response of magnesium-substituted nanobioactive glass particles for biomedical applications. Ceram. Int. 2013, 39, 1683-1694. [CrossRef]

106. Ferguson, J.B.; Merwin, H.E. The ternary system CaO-MgO-SiO 2 . Proc. Natl. Acad. Sci. USA 1904, 13, 16. [CrossRef]

107. Wu, C.; Chang, J.; Wang, J.; Ni, S.; Zhai, W. Preparation and characteristics of a calcium magnesium silicate (bredigite) bioactive ceramic. Biomaterials 2005, 26, 2925-2931. [CrossRef] 
108. Pouroutzidou, G.K.; Theodorou, G.S.; Kontonasaki, E.; Papadopoulou, L.; Kantiranis, N.; Patsiaoura, D.; Chrissafis, K.; Lioutas, C.B.; Paraskevopoulos, K.M. Synthesis of a bioactive nanomaterial in the ternary system $\mathrm{SiO}_{2}-\mathrm{CaO}-\mathrm{MgO}$ doped with CuO: The effect of Ball milling on the particle size, morphology and bioactive behavior. In AIP Conference Proceedings; AIP Publishing: New York, NY, USA, 2019; Volume 2075, p. 200005.

109. Goudouri, O.M.; Chatzistavrou, X.; Kontonasaki, E.; Kantiranis, N.; Papadopoulou, L.; Chrissafis, K.; Paraskevopoulos, K.M. Study of the Bioactive Behavior of Thermally Treated Modified 58S Bioactive Glass. Key Eng. Mater. 2009, 396-398, 131-134. [CrossRef]

110. Yamagata, C.; Paiva, M.R.S.; Higa, O.Z.; Rodas, A.D.; Silveira, A.C.F.; Reis, S.T.; Paulo, S. Sol Gel Modified Derived CaO-MgO$\mathrm{SiO}_{2}$ Ceramic Glass System: Preparation and In Vitro. 1969. Available online: https://www.ipen.br/biblioteca/2013/eventos/ 19086.pdf (accessed on 23 October 2019).

111. Goudouri, O.-M.; Kontonasaki, E.; Papadopoulou, L.; Kantiranis, N.; Lazaridis, N.; Chrissafis, K.; Chatzistavrou, X.; Koidis, P.; Paraskevopoulos, K. Towards the synthesis of an experimental bioactive dental ceramic. Part I: Crystallinity characterization and bioactive behavior evaluation. Mater. Chem. Phys. 2014, 145, 125-134. [CrossRef]

112. Cacciotti, I.; Lombardi, M.; Bianco, A.; Ravaglioli, A.; Montanaro, L. Sol-gel derived 45 S5 bioglass: Synthesis, microstructural evolution and thermal behaviour. J. Mater. Sci. Mater. Med. 2012, 23, 1849-1866. [CrossRef]

113. Groh, D.; Döhler, F.; Brauer, D.S. Bioactive glasses with improved processing. Part 1. Thermal properties, ion release and apatite formation. Acta Biomater. 2014, 10, 4465-4473. [CrossRef]

114. Cacciotti, I. Cationic and Anionic Substitutions in Hydroxyapatite; Springer: Berlin/Heidelberg, Germany, 2016; ISBN 9783319124605.

115. Mohammadi, H.; Hafezi, M.; Nezafati, N.; Heasarki, S.; Nadernezhad, A.; Ghazanfari, S.M.H.H.; Sepantafar, M. Bioinorganics in Bioactive Calcium Silicate Ceramics for Bone Tissue Repair: Bioactivity and Biological Properties. J. Ceram. Sci. Technol. 2014, 5, 1-12. [CrossRef]

116. Rismanchian, M.; Khodaeian, N.; Bahramian, L.; Fathi, M.H.; Sadeghi-Aliabadi, H. In-vitro Comparison of Cytotoxicity of Two Bioactive Glasses in Micropowder and Nanopowder forms. Iran. J. Pharm. Res. 2013, 12, 437-443.

117. Abiraman, S.; Varma, H.K.; Kumari, T.V.; Umashankar, P.R.; John, A. Preliminaryin vitro andin vivo characterizations of a sol-gel derived bioactive glass-ceramic system. Bull. Mater. Sci. 2002, 25, 419-429. [CrossRef]

118. Ferraris, S.; Yamaguchi, S.; Barbani, N.; Cazzola, M.; Cristallini, C.; Miola, M.; Vernè, E.; Spriano, S. Bioactive materials: In vitro investigation of different mechanisms of hydroxyapatite precipitation. Acta Biomater. 2020, 102, 468-480. [CrossRef]

119. Brito, A.F.; Antunes, B.; Dos Santos, F.; Fernandes, H.R.; Ferreira, J.M.F. Osteogenic capacity of alkali-free bioactive glasses. In vitro studies. J. Biomed. Mater. Res. Part B Appl. Biomater. 2016, 105, 2360-2365. [CrossRef]

120. Hench, L.L.; Jones, J.R.; Sepulveda, P. Bioactive Materials for Tissue Engineering Scaffolds. In Future Strategies for Tissue and Organ Replacement; Imperial College Press: London, UK, 2002; pp. 3-24.

121. Karadjian, M.; Essers, C.; Tsitlakidis, S.; Reible, B.; Moghaddam, A.; Boccaccini, A.R.; Westhauser, F. Biological Properties of Calcium Phosphate Bioactive Glass Composite Bone Substitutes: Current Experimental Evidence. Int. J. Mol. Sci. 2019, 20, 305. [CrossRef]

122. Schmitz, S.; Widholz, B.; Essers, C.; Becker, M.; Tulyaganov, D.; Moghaddam, A.; de Juan, I.G.; Westhauser, F. Superior biocompatibility and comparable osteoinductive properties: Sodium-reduced fluoride-containing bioactive glass belonging to the $\mathrm{CaO}-\mathrm{MgO}-\mathrm{SiO}_{2}$ system as a promising alternative to $45 \mathrm{~S} 5$ bioactive glass. Bioact. Mater. 2020, 5, 55-65. [CrossRef]

123. Detsch, R.; Guillon, O.; Wondraczek, L.; Boccaccini, A.R. Initial Attatchment of rMSC and MG-63 Cells on Patterned Bioglass ${ }^{\circledR}$ Substrates. Adv. Eng. Mater. 2012, 14, B38-B44. [CrossRef]

124. Aljarah, A.K.; Al-Saadi, A.H.; Auda, N.A. ELK1 Gene Transfection Effect in Prostate Cancer Cell Line Proliferation Activity. Adv. Life Sci. Technol. 2014, 6597, 1-6.

125. Chang, J.-S.; Chang, K.L.B.; Hwang, D.-F.; Kong, Z.-L. In Vitro Cytotoxicitiy of Silica Nanoparticles at High Concentrations Strongly Depends on the Metabolic Activity Type of the Cell Line. Environ. Sci. Technol. 2007, 41, 2064-2068. [CrossRef]

126. Tsigkou, O.; Jones, J.; Polak, J.M.; Stevens, M.M. Differentiation of fetal osteoblasts and formation of mineralized bone nodules by $45 \mathrm{~S} 5$ Bioglass ${ }^{\circledR}$ conditioned medium in the absence of osteogenic supplements. Biomaterials 2009, 30, 3542-3550. [CrossRef] [PubMed]

127. Lehman, S.E.; Morris, A.S.; Mueller, P.S.; Salem, A.; Grassian, V.H.; Larsen, S.C. Silica nanoparticle-generated ROS as a predictor of cellular toxicity: Mechanistic insights and safety by design. Environ. Sci. Nano 2016, 3, 56-66. [CrossRef]

128. Ha, S.-W.; Sikorski, J.A.; Weitzmann, M.N.; Beck, G.R. Bio-active engineered 50nm silica nanoparticles with bone anabolic activity: Therapeutic index, effective concentration, and cytotoxicity profile in vitro. Toxicol. Vitr. 2014, 28, 354-364. [CrossRef] [PubMed]

129. Alcaide, M.; Portolés, P.; López-Noriega, A.; Arcos, D.; Vallet-Regí, M.; Portolés, M. Interaction of an ordered mesoporous bioactive glass with osteoblasts, fibroblasts and lymphocytes, demonstrating its biocompatibility as a potential bone graft material. Acta Biomater. 2010, 6, 892-899. [CrossRef]

130. Hoppe, A.; Güldal, N.S.; Boccaccini, A.R. A review of the biological response to ionic dissolution products from bioactive glasses and glass-ceramics. Biomaterials 2011, 32, 2757-2774. [CrossRef]

131. Xie, W.; Chen, X.; Miao, G.; Tang, J.; Fu, X. Regulation of cellular behaviors of fibroblasts related to wound healing by sol-gel derived bioactive glass particles. J. Biomed. Mater. Res. Part A 2016, 104, 2420-2429. [CrossRef] [PubMed]

132. Ciraldo, F.E.; Boccardi, E.; Melli, V.; Westhauser, F.; Boccaccini, A.R. Tackling Bioactive Glass Excessive in Vitro Bioreactivity: Preconditioning Approaches for Cell Culture Tests. Acta Biomater. 2018, 75, 3-10. [CrossRef] [PubMed] 
133. Hohenbild, F.; Arango-Ospina, M.; Moghaddam, A.; Boccaccini, A.R.; Westhauser, F. Preconditioning of Bioactive Glasses before Introduction to Static Cell Culture: What Is Really Necessary? Methods Protoc. 2020, 3, 38. [CrossRef] [PubMed]

134. Torres-lagares, D. Biocompatibility of Polymer and Ceramic CAD/CAM. Polymers 2019, 11, 446.

135. Laranjeira, M.S.; Carvalho, Â.; Pelaez-Vargas, A.; Hansford, D.; Ferraz, M.P.; Coimbra, S.; Monteiro, F.J. Modulation of human dermal microvascular endothelial cell and human gingival fibroblast behavior by micropatterned silica coating surfaces for zirconia dental implant applications. Sci. Technol. Adv. Mater. 2014, 15, 25001. [CrossRef]

136. Wananuruksawong, R.; Wasanapiarnpong, T.; Dhanesuan, N.; Didron, P.P. Microhardness and Biocompatibility of Silicon Nitride Ceramic Developed for Dental Applications. Mater. Sci. Appl. 2014, 5, 1034-1039. [CrossRef]

137. Atay, A.; Gürdal, I.; Cetintas, V.B.; Üşümez, A.; Cal, E. Effects of New Generation All-Ceramic and Provisional Materials on Fibroblast Cells. J. Prosthodont. 2018, 28, e383-e394. [CrossRef] [PubMed]

138. Yu, H.; Peng, J.; Xu, Y.; Chang, J.; Li, H. Bioglass Activated Skin Tissue Engineering Constructs for Wound Healing. ACS Appl. Mater. Interfaces 2016, 8, 703-715. [CrossRef] [PubMed]

139. Chung, T.-H.; Wu, S.-H.; Yao, M.; Lu, C.-W.; Lin, Y.-S.; Hung, Y.; Mou, C.-Y.; Chen, Y.-C.; Huang, D.-M. The effect of surface charge on the uptake and biological function of mesoporous silica nanoparticles in 3T3-L1 cells and human mesenchymal stem cells. Biomaterials 2007, 28, 2959-2966. [CrossRef]

140. Tavakoli, M.; Bateni, E.; Rismanchian, M.; Fathi, M.; Doostmohammadi, A.; Rabiei, A.; Sadeghi, H.; Etebari, M.; Mirian, M. Genotoxicity Effects of Nano Bioactive Glass and Novabone Bioglass on Gingival Fibroblasts Using Single Cell Gel Electrophoresis (Comet Assay): An in Vitro Study. Dent. Res. J. 2012, 9, 314-320. [CrossRef]

141. Miguez-Pacheco, V.; Greenspan, D.; Hench, L.L.; Boccaccini, A.R. Bioactive Glasses in Soft Tissue Repair. Biomaterials 2015, 94, 27-31.

142. Kargozar, S.; Hamzehlou, S.; Baino, F. Potential of bioactive glasses for cardiac and pulmonary tissue engineering. Materials 2017, 10, 1429. [CrossRef]

143. Hensley, K.; A Robinson, K.; Gabbita, S.; Salsman, S.; A Floyd, R. Reactive oxygen species, cell signaling, and cell injury. Free. Radic. Biol. Med. 2000, 28, 1456-1462. [CrossRef]

144. Zhang, L.; Laug, L.; Münchgesang, W.; Pippel, E.; Gösele, U.; Brandsch, M.; Knez, M. Reducing Stress on Cells with ApoferritinEncapsulated Platinum Nanoparticles. Nano Lett. 2010, 10, 219-223. [CrossRef] [PubMed]

145. Richter, C.; Gogvadze, V.; Laffranchi, R.; Schlapbach, R.; Schweizer, M.; Suter, M.; Walter, P.; Yaffee, M. Oxidants in mitochondria: From physiology to diseases. Biochim. Biophys. Acta (BBA)-Mol. Basis Dis. 1995, 1271, 67-74. [CrossRef]

146. Lamkhao, S.; Phaya, M.; Jansakun, C.; Chandet, N.; Thongkorn, K.; Rujijanagul, G.; Bangrak, P.; Randorn, C. Synthesis of Hydroxyapatite with Antibacterial Properties Using a Microwave-Assisted Combustion Method. Sci. Rep. 2019, 9, 4015. [CrossRef] [PubMed]

147. Hu, S.; Chang, J.; Liu, M.; Ning, C. Study on antibacterial effect of 45 S5 Bioglass ${ }^{\circledR}$. J. Mater. Sci. Mater. Med. 2009, 20, 281-286. [CrossRef]

148. Ma, N.; Fan, X.; Quan, X.; Zhang, Y. Ag- $\mathrm{TiO}_{2} / \mathrm{HAP} / \mathrm{Al}_{2} \mathrm{O}_{3}$ bioceramic composite membrane: Fabrication, characterization and bactericidal activity. J. Membr. Sci. 2009, 336, 109-117. [CrossRef]

149. Kolmas, J.; Groszyk, E.; Kwiatkowska-ró, D. Buttonwood: All It Needs Is Love. Economist 2014, 3-16. Available online: www.theguardian.com/environment/2014/oct/02/uk-renewable-energy-subsidy-changes-anger-solar-industry (accessed on 6 March 2015).

150. Hancock, J.T.; Desikan, R.; Neill, S. Role of reactive oxygen species in cell signalling pathways. Biochem. Soc. Trans. 2001, 29, 345-349. [CrossRef]

151. Son, Y.; Cheong, Y.-K.; Kim, N.-H.; Chung, H.-T.; Kang, D.G.; Pae, H.-O. Mitogen-Activated Protein Kinases and Reactive Oxygen Species: How Can ROS Activate MAPK Pathways? J. Signal Transduct. 2011, 2011, 792639. [CrossRef]

152. Muller, F.L.; Lustgarten, M.S.; Jang, Y.; Richardson, A.; Van Remmen, H. Trends in oxidative aging theories. Free Radic. Biol. Med. 2007, 43, 477-503. [CrossRef]

153. Wellen, K.E.; Thompson, C.B. Cellular Metabolic Stress: Considering How Cells Respond to Nutrient Excess. Mol. Cell 2010, 40, 323-332. [CrossRef]

154. Huang, X.; Zhuang, J.; Teng, X.; Li, L.; Chen, D.; Yan, X.; Tang, F. The promotion of human malignant melanoma growth by mesoporous silica nanoparticles through decreased reactive oxygen species. Biomaterials 2010, 31, 6142-6153. [CrossRef]

155. He, Q.; Shi, J. Mesoporous silica nanoparticle based nano drug delivery systems: Synthesis, controlled drug release and delivery, pharmacokinetics and biocompatibility. J. Mater. Chem. 2011, 21, 5845-5855. [CrossRef]

156. He, Q.; Zhang, J.; Chen, F.; Guo, L.; Zhu, Z.; Shi, J. An Anti-ROS/Hepatic Fibrosis Drug Delivery System Based on Salvianolic Acid B Loaded Mesoporous Silica Nanoparticles. Biomaterials 2010, 31, 7785-7796. [CrossRef]

157. Asharani, P.V.; Mun, G.L.K.; Hande, M.P.; Valiyaveettil, S. Cytotoxicity and Genotoxicity of Silver Nanoparticles in Human Cells. ACS Nano 2009, 3, 279-290. [CrossRef] [PubMed]

158. Willson, R.L. Hydroxyl Radicals and Biological Damage in Vitro: What Relevance in Vivo? Ciba Foundation symposium. In Oxygen Free Radicals and Tissue Damage; Excerpta Medica Amsterdam: Amsterdam, The Netherlands, 1979 ; pp. 19-42.

159. Jiang, L.; Yu, Y.; Li, Y.; Yu, Y.; Duan, J.; Zou, Y.; Li, Q.; Sun, Z. Oxidative Damage and Energy Metabolism Disorder Contribute to the Hemolytic Effect of Amorphous Silica Nanoparticles. Nanoscale Res. Lett. 2016, 11, 57. [CrossRef] [PubMed] 
160. Napierska, D.; Rabolli, V.; Thomassen, L.C.J.; Dinsdale, D.; Princen, C.; Gonzalez, L.; Poels, K.L.C.; Kirsch-Volders, M.; Lison, D.; Martens, J.; et al. Oxidative Stress Induced by Pure and Iron-Doped Amorphous Silica Nanoparticles in Subtoxic Conditions. Chem. Res. Toxicol. 2012, 25, 828-837. [CrossRef] [PubMed]

161. Mihailova, I.K.; Radev, L.; Aleksandrova, V.A.; Colova, I.V. Novel Merwinite/Akermanite Ceramics: In Vitro Bioactivity. Bulg. Chem. Commun. 2015, 47, 253-260. 